\title{
Landscape evolution and agro-sylvo-pastoral activities on the Gorgan Plain (NE Iran) in the last 6000 years
}

\author{
Lyudmila S Shumilovskikh, ${ }^{1,2,3}$ Kristen Hopper, ${ }^{4}$ Morteza Djamali, \\ Philippe Ponel,' François Demory, ${ }^{5}$ Frauke Rostek, ${ }^{5}$ \\ Kazuyo Tachikawa, ${ }^{5}$ Felix Bittmann, ${ }^{6}$ Alexandra Golyeva, ${ }^{7}$ \\ Frédéric Guibal,' Brigitte Talon,' Liang-Chi Wang, ${ }^{8}$ \\ Masoud Nezamabadi, ${ }^{9}$ Edouard Bard, ${ }^{5}$ Hamid Lahijani, ${ }^{10}$ \\ Jebrael Nokandeh, ${ }^{9}$ Hamid Omrani Rekavandi, " I \\ Jacques-Louis de Beaulieu,' Eberhard Sauer ${ }^{12}$ \\ and Valérie Andrieu-Ponel'
}

\begin{abstract}
The Gorgan Plain (NE Iran) is characterized by fertile soils formed on a loess plateau and is at present primarily exploited for intensive agriculture. However, the timing and intensity of the human impact on the landscape in the past are still unclear. A sediment core, taken from the centre of the eastern Gorgan Plain in the Kongor Lake covering the major part of the Holocene from 6.1 to 0.8 ka (all ages are calibrated before present), has been studied for pollen, non-pollen palynomorphs, botanical macroremains, insects, charcoal, geochemistry, biomarkers and magnetism in order to provide new insights into the evolution of the landscape and to estimate the intensity of human activities. The data obtained suggest a dry period between 5.9 and 3.9 ka and an increase in regional humidity afterwards with a maximum between 2.7 and $0.7 \mathrm{ka}$, during the period of the Persian empires (Achaemenid through Sasanian) and the Islamic era. The eastern part of the Gorgan Plain was characterized by open steppe landscapes during the last 6 ka, which most likely were used for pasture and at least since $2.7 \mathrm{ka}$ for agriculture including arboriculture. The strongest anthropogenic impact on the environment around the Kongor site is documented during the Parthian and Sasanian Empires (200 BC-65I AD) and the Islamic era up to the eve of the Mongol invasion.
\end{abstract}

\section{Keywords}

Achaemenid, biomarkers, Bronze Age, environmental magnetism, geochemistry, Iron Age, Islamic era, non-pollen palynomorphs, palaeoentomology, palynology, Parthian, Sasanian

Received 3 December 2015; revised manuscript accepted 22 March 2016

\section{Introduction}

The Gorgan Plain (NE Iran) is located at the southeastern corner of the Caspian Sea between the Alborz Mountains and the Turkmen steppe (Figure 1a). The Plain was built up by Quaternary alluvial and loess deposits and is characterized by fertile soils (Asadi et al.,

'Institut Méditerranéen de Biodiversité et d'Ecologie marine et continentale (IMBE), Aix-Marseille Université, CNRS, IRD, Avignon Université, France

2Laboratory of Plant Taxonomy and Phylogeny, Tomsk State University, Russia

${ }^{3}$ Department Palynology and Climate Dynamics, Georg-August-

Universität Göttingen, Germany

${ }^{4}$ Department of Archaeology, Durham University, UK

${ }^{5}$ Aix-Marseille Université, CNRS, IRD, Collège de France, CEREGE UM34, France

'Lower Saxony Institute for Historical Coastal Research, Germany

${ }^{7}$ Institute of Geography Russian Academy of Science, Russia
2013). It is not surprising that the Gorgan Plain is primarily exploited for intensive agriculture of mainly wheat and soya. Pastoralism occurs in a seasonal cycle with summer pastures in the mountains and winter pastures on the plain. The Gorgan Plain has

${ }^{8}$ Collection Management Department, National Taiwan Museum, Taiwan ${ }^{9}$ National Museum of Iran, Iran

10Marine Geology Department, Iranian National Institute for Oceanography and Atmospheric Science (INIOAS), Iran

I'Iranian Cultural Heritage, Handcraft and Tourism Organization, Iran

${ }^{12}$ School of History, Classics and Archaeology, University of Edinburgh, UK

Corresponding author:

Lyudmila S Shumilovskikh, Department of Palynology and Climate Dynamics, Georg-August University Göttingen, Untere Karspüle 2, 37073 Göttingen, Germany.

Email: shumilovskikh@gmail.com 

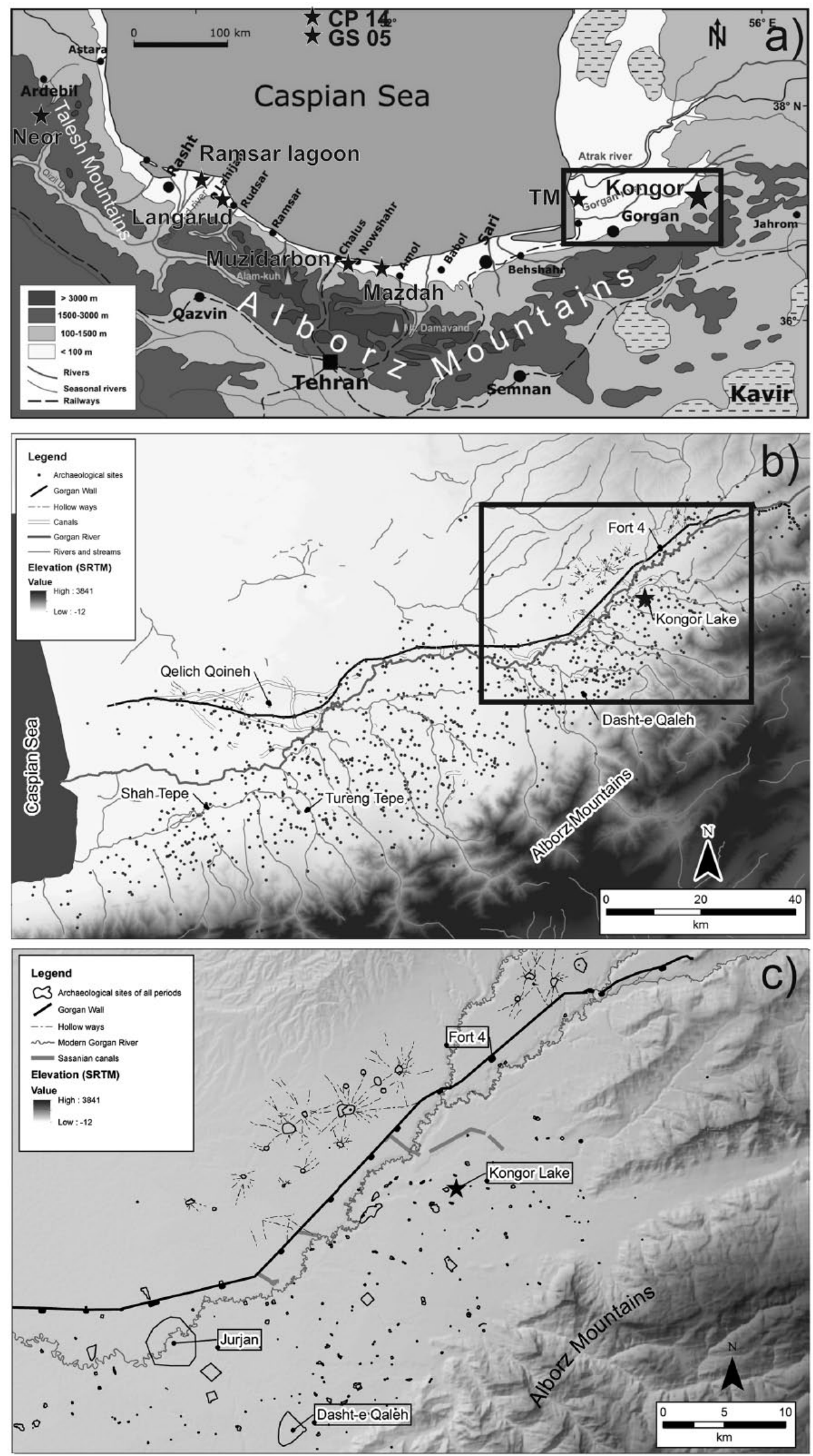

Figure I. Overview map: (a) southern Caspian Sea shore with the location of sites discussed in the text; (b) archaeological sites and landscape features of all periods from published sources (Abbasi, 20I I;Arne, 1945; Kiani, 1982; Shiomi, 1976, 1978; Wilkinson et al., 2013) and the remote sensing of CORONA satellite imagery; and (c) archaeological sites and landscape features on the eastern Gorgan Plain investigated through field survey and the remote sensing of satellite imagery by the Persia and Its Neighbours Project. To the south of the Gorgan Wall, large geometric fortifications and canals of the Sasanian period are clearly visible. Hollow ways radiating out from sites are also visible north of the Gorgan River. Key sites mentioned in the text and the location of Kongor Lake are indicated. Elevation data - SRTM 90 m resolution (data available from U.S. Geological Survey). 
a long settlement history (Figure 1b, section Archaeological investigations), but the timing and intensity of the human impact on the landscape in the past are still unclear.

In comparison to the Zagros Mountains, which has been the focus of study for a much longer period of time (e.g. Djamali et al., 2009b, 2011b, 2015; Van Zeist, 1967; Van Zeist and Bottema, 1977, 1991; Van Zeist and Wright, 1963), the vegetation and environmental history of the Alborz Mountains is less well known, and evidence for the timing and magnitude of anthropogenic imprints on landscape evolution is still sparse (Kehl, 2009). Recent studies show that the highlands of the western part of the Alborz experienced typical Holocene climatic changes from dry and dusty (11-9ka), rather wet (9-6 ka) and a return to dry and dusty again (6 ka-present) (all ages are calibrated) (Sharifi et al., 2015). Combined records of GS05 and CP14 from the southern Caspian Sea reflect major late glacial and Holocene climate and vegetation changes in comparison to the Caspian Sea level changes (Leroy et al., 2013b). In the coastal area of the Caspian Sea, Hyrcanian forest vegetation shows clear reaction to the Caspian Sea level oscillations (Ramezani et al., 2016) and to the 'Little Ice Age' (Haghani et al., 2015; Leroy et al., 2011). The Holocene vegetation history of the eastern part of the Alborz Mountains has been studied on a lagoonal core from the SE Caspian Sea (Leroy et al., 2013a), providing general vegetation changes during the highstands of the Caspian Sea at 10.6-7.2 ka and $3.5 \mathrm{ka}$-present from deciduous Quercus to Carpinus betulus, Parrotia persica and Fagus orientalis-Pterocarya fraxinifolia. The cores from the central part of the south Caspian Sea have a very large pollen source area, including the Caucasian and Hyrcanian forests and the deserts of Kazakhstan and Turkmenistan (Leroy et al., 2007). Therefore, peat or lake cores are more suitable for local environmental reconstructions of the Gorgan Plain.

Considering the anthropogenic impact on vegetation, four records are relevant. In the Talysh Mountains, pollen and beetles from the alpine Neor Lake revealed Irano-Turanian montane steppe during the last $6.7 \mathrm{ka}$ and suggest long-term human impact (Ponel et al., 2013). In the central Alborz Mountains, vegetation history is known for the last 3000 years, detecting an anthropogenic impact on the vegetation by deforestation and tree cultivation especially over the last two centuries (Ramezani et al., 2008, 2016). The lagoonal core TM in the eastern Caspian Sea provides evidence for a Pterocarya decrease since the 6th century AD as a result of deforestation or aridification, whereas Plantago and Juglans suggest that landscapes were modified by humans through pastoralism and arboriculture (Leroy et al., 2013a).

In this study, a sediment core from Kongor Lake in the centre of the eastern Gorgan Plain has been studied for pollen, non-pollen palynomorphs, botanical macroremains, insects, charcoal, geochemistry and magnetism. The aim of the study is to provide new insights into the landscape evolution and to estimate the intensity of agriculture, livestock breeding, exploitation of natural resources, and environmental impact of these activities, and vice versa, the influence of the natural environment and climate on civilizations.

\section{Geographical settings}

Geographically, the Gorgan Plain is located in the southeast lowlands of the Caspian Sea at the foot of the Alborz Mountains of northern Iran, in the province of Golestan. It is primarily composed of Quaternary loess and alluvial deposits (Asadi et al., 2013). The modern climate of the southeast corner of the Caspian Sea is different from its other 14 climate regions and is characterized by a long-standing summer season. The dominant winds during spring and summer blow from the west and northwest, while northerly (NN, NW and NE) winds are dominant in fall and winter (Terziev, 1992) and may transport dust from local sources
(Lahijani and Tavakoli, 2012). The climate is Csa following the Köppen-Geiger classification with a mean annual temperature of $\sim 18^{\circ} \mathrm{C}$ and mean precipitation ranging from 350 to $1300 \mathrm{~mm}$. Unlike the southwest Caspian region, which has a temperate to subtropical oceanic bioclimate without a dry season, the Gorgan Plain is characterized by a Mediterranean xeric to oceanic bioclimate with the dry season lasting as long as 3 to 4 months (Djamali et al., 2011a; Sagheb Talebi et al., 2014).

The Caspian Sea is the major source of moisture, transported by dominant northeastern and northwestern winds (Khalili, 1973; Leroy et al., 2011; Molavi-Arabshahi et al., 2015; Sagheb Talebi et al., 2014). The Alborz Mountains prevent moisture transport into the central parts of Iran, causing orographic rainfall on the northern slopes of the mountains (Khalili, 1973) and abrupt changes in the precipitation regime along a south-north gradient from $1300 \mathrm{~mm}$ over the Alborz Mountains to $600-700 \mathrm{~mm}$ in the piedmont and down to $200 \mathrm{~mm}$ in Turkmen steppe. Precipitation decreases also with distance from the Caspian Sea in a west-east gradient from $500 \mathrm{~mm}$ in Gorgan to $350 \mathrm{~mm}$ in Gonbad-Kavus (Akhani et al., 2010; Sagheb Talebi et al., 2014).

According to the precipitation regime, potential vegetation is represented by Hyrcanian forests on the northern slopes of the Alborz Mountains, and Iranian steppes of the Artemisietea herbae-albae iranica, Irano-Turanian psammophilous vegetation and saltland vegetation of the Salicornietea are found in the lowlands (Gerasimov, 1964; Zohary, 1973). According to Zohary (1981), the Hyrcanian forests are represented by arboreal communities of three classes: Alnetea hyrcanica on the Caspian foreshore and its streamways with Alnus, Fraxinus, Pterocarya, Gleditsia, Albizia, Buxus, Celtis, Ficus and Punica; Zelkovo-Parrotietea on hills and lower mountain zones with Zelkova carpinifolia, Parrotia persica, Quercus castaneifolia and Carpinus betulus; Fagetea hyrcanica in the higher mountain zone with Fagus orientalis, Acer velutinum and A. campestre. Above $2000 \mathrm{~m}$, vegetation is represented by Quercus and Juniperus. There is a marked difference in the floristic composition of the Hyrcanian forest in the west and east, so that the eastern section has a more xerophilous flora than the western section (Akhani et al., 2010), reflecting gradient from a temperate oceanic to a more continental climate. For instance, Fagus orientalis, which dominates the montane forest zone in the western and central Hyrcanian forest, is absent to the east of Gorgan (Akhani et al., 2010; Djamali et al., 2011a). Today, the Gorgan Plain is intensively exploited for agricultural and pastoral activities. Precipitation patterns seem to be the major determining factor in the geographical distribution of different agro-pastoral practices with rain-fed cultivation concentrated in the piedmont plains, irrigated wheat cultivation on the alluvial plains and grazing further to the north, especially in the Turkmen steppe (Wilkinson et al., 2013).

The Kongor Lake, located in the eastern part of the Gorgan Plain, presents a small $(80 \times 200 \mathrm{~m})$ temporary lake fed by ground and rain water. It is filled in winter and spring, but dries out during summer and autumn. Water level changes reach 8 to $10 \mathrm{~m}$; local informants indicate that 50-60 years ago during high water stands, the water could be transferred to the next village by a canal. Currently, it is used for fish breeding and the irrigation of the surrounding rice and wheat plantations. The wetland formation seems to be related to the high groundwater in the vicinity of the Gorgan River. It is possible that the small depression has been formed by aeolian deflation during the last glacial period. Locally, the vegetation around the lake is composed of Salix, Populus, Rubus, Achnatherum splendens, Phragmites, Abutilon theophrasti, Xanthium strumarium, Polygonum persicaria group, Cyperus sp., Chenopodium sp., Convolvulus, Galium, Poaceae, Asteraceae as well as planted Pinus, Ficus carica, Morus alba, Prunus, Juglans regia and Vitis vinifera. 


\section{Archaeological investigations}

Archaeological investigations have been undertaken on the Gorgan Plain since the late 1800 s, and as such, a vast number of archaeological sites and landscape features have been recorded representing settlements from the prehistoric through to the more recent times (Abbasi, 2011; Arne, 1945; De Morgan, 1902; Kiani, 1982; Nokandeh et al., 2006; Omrani Rekavandi et al., 2007, 2008; Schmidt, 1940; Shiomi, 1976, 1978; Wilkinson et al., 2013) (Figure 1b). Our understanding of long-term settlement development and land use in the plain, however, is limited by the lack of an absolutely dated stratified ceramic assemblage from any one site, as well as incomplete publication, or accessibility of the material (see Thornton (2013) for a discussion of this problem for the prehistoric periods). However, the available data from published surveys and ongoing investigations suggest that the density of settlement, in most periods, has been mainly concentrated to the south of the Gorgan River where precipitation is higher (Abbasi, 2011; Arne, 1945; Shiomi, 1976, 1978).

This is particularly the case with the prehistoric periods, where the vast majority of sites were located in the southern part of the plain. Very few Neolithic sites have been found, and they are probably underrepresented due to non-intensive survey methodologies, or at multi-period sites burial under later occupations, or, as has been observed at sites such as Tureng Tepe, the position of these early layers below the modern water table (Boucharlat and Lecomte, 1987). This picture, however, is changing; new and forthcoming publications by Iranian archaeologists will hopefully increase our knowledge of this period substantially (see Roustaei, 2016). Material from excavations at sites such as Tureng Tepe and Shah Tepe (Figure 1b) indicates an increase in the social complexity of the communities inhabiting the plain from the mid to late 4th millennium BC onwards, while survey data suggest a substantial increase in the number of settlements at the beginning of the Bronze Age (ca. early 3rd millennium BC) (Abbasi, 2011; Arne, 1945; Thornton, 2013). A significant decrease in settlement appears to occur sometime in the first half of the 2nd millennium $\mathrm{BC}$ with evidence for abandonment at several excavated sites (Abbasi, 2011; Crawford, 1963; Deshayes, 1975). Currently, we have a very poor understanding of the transition between the Late Bronze Age and the early Iron Age in the region because of a lack of archaeological evidence from the early second millennium BC through the early first millennium BC.

An increase in the number of sites on the plain appears to occur by the Iron III period (ca. 8th-5th centuries BC). Excavations at the site of Qelich Qoineh in the western plain (Figure 1b) have allowed for the dating of this horizon (Sauer et al. 2013), and comparable ceramic assemblages are found on numerous sites both north and south of the Gorgan River, and much further north in the Misrian Plain of Southern Turkmenistan though further survey is needed to fully understand the extent of settlement in this phase (Cleuziou, 1985; Kohl, 1984; Wilkinson et al., 2013). Prior to this period, settlement density to the north of the Gorgan River appears to be low. This pattern of settlement in the northern part of the plain seems to persist with the following Iron IV (and possibly Parthian) period. Further chronological refinement is needed to properly elucidate the extent of settlement corresponding to these periods, though it is likely that the plain continued to be densely occupied (Abbasi, 2011; Priestman, 2013). Irrigation canals located north of the Gorgan River in the western plain are likely concurrent with Iron Age settlements, and distinct 'hollow ways' or routes radiating out from Iron III and IV sites in the eastern plain suggest the movement of people and animals beyond the limits of cultivation around the sites (Wilkinson et al., 2013). At Qelich Qoineh, analysis of the faunal remains from the town-like phases of the site indicates the exploitation of suids, cattle and caprines in descending importance, while the latest rather ephemeral settlement phase at the site appears to be dominated by caprines (Mashkour et al., 2013).
Between the 5th and 6th/7th centuries AD, the Sasanian Empire invested heavily in defensive infrastructure on the plain as evidenced by the construction of the ca. $200 \mathrm{~km}$ long Gorgan Wall and its associated forts, numerous geometric fortresses and canals (Nokandeh et al., 2006; Omrani Rekavandi et al., 2007, 2008; Sauer et al., 2013). The Gorgan Wall roughly follows the natural frontier between the more arid regions north of the Gorgan River and the fertile plains in the south. Perhaps unsurprisingly, there are very few sites securely datable to the Sasanian period located north of the wall (Wilkinson et al., 2013). Faunal assemblages from excavated Sasanian contexts in the eastern Gorgan Plain also provide an insight into the type of animal exploitation occurring during this period; at the urban site of Dasht-e Qaleh (Figure 1c), sheep and goat dominated, while cattle herding is clearly practised at sites such as Fort 4 along the Gorgan Wall (Mashkour et al., 2013).

\section{Methods}

\section{Stratigraphy and age-depth model}

The sediment core extracted from Kongor Lake $\left(37^{\circ} 21^{\prime} 21^{\prime \prime} \mathrm{N}\right.$, $55^{\circ} 23^{\prime} 27^{\prime \prime}$ E, 93 m a.s.1.) by semi-cylindrical chamber corer $(100 \mathrm{~cm}$ long, $10 \mathrm{~cm}$ diameter) is composed of sandy clays in the lower metre developing to gyttja in the upper two metres (Figure 2). To establish a chronological framework, nine AMS radiocarbon dates were obtained from bulk sediment, charred grasses and macroremains at the Radiocarbon Laboratory of Poznan (Table 1). An age-depth model (Figure 2) was constructed using the clam in R (Blaauw, 2010) with linear interpolation.

\section{Palynology}

For palynological analyses, 53 subsamples were collected from the entire core with intervals of $2-8 \mathrm{~cm}$. Laboratory treatment included cold $\mathrm{HCl}(37 \%)$, acetolysis (3-4 min) and sieving on 10 and $200 \mu \mathrm{m}$. In order to calculate concentrations, Lycopodium tablets (Batch number 1031) were added to each sample. The remaining pellet was stored in glycerine and studied under $500 \times$ to $1250 \times$ magnification. Pollen identification has been carried out with the help of literature (Beug, 2004) and a reference collection. In every sample, a minimum of 300 terrestrial pollen were counted (310 \pm $10)$ and this sum was used for calculations of taxa proportions. In order to obtain extra palaeoecological information, non-pollen palynomorphs (NPP) (e.g. Haas, 1994; Van Geel, 1978; Van Geel and Aptroot, 2006) were recorded. Zonation of the diagram is based on changes of the principal component analysis (PCA) axes.

Based on the ecological requirement of major non-arboreal pollen (NAP) taxa Poaceae, Artemisia and Chenopodiaceae (now Amarantaceae), a moisture index (MI) was calculated as a ratio (Artemisia + Poaceae)/Chenopodiaceae. Poaceae and Artemisia are more important in the semi-arid regions (steppe, dry steppe), and their pollen contribute to higher index values, indicating wetter conditions. In contrast, Chenopodiaceae are extremely drought-tolerant and distributed in harsh climates, contributing to a decrease in the MI, indicating dryer conditions (El-Moslimany, 1990; Herzschuh, 2007).

\section{Macroremains}

In order to reconstruct local conditions, the sediment was studied for macroremains including botanical rests, insects (mainly Coleoptera), charcoal, molluscs and ostracods. For this purpose, 19 samples, each 4-cm thick, were water-sieved on sieves with mesh size of 200 and 400 or $500 \mu \mathrm{m}$. Macroremains were picked out by hand using a stereomicroscope with $40 \times$ to $100 \times$ magnification. Identification of botanical and charred remains was carried out using the library and reference collections

The insect and other arthropod remains were preserved in alcohol. Identifications were made using a modern reference 


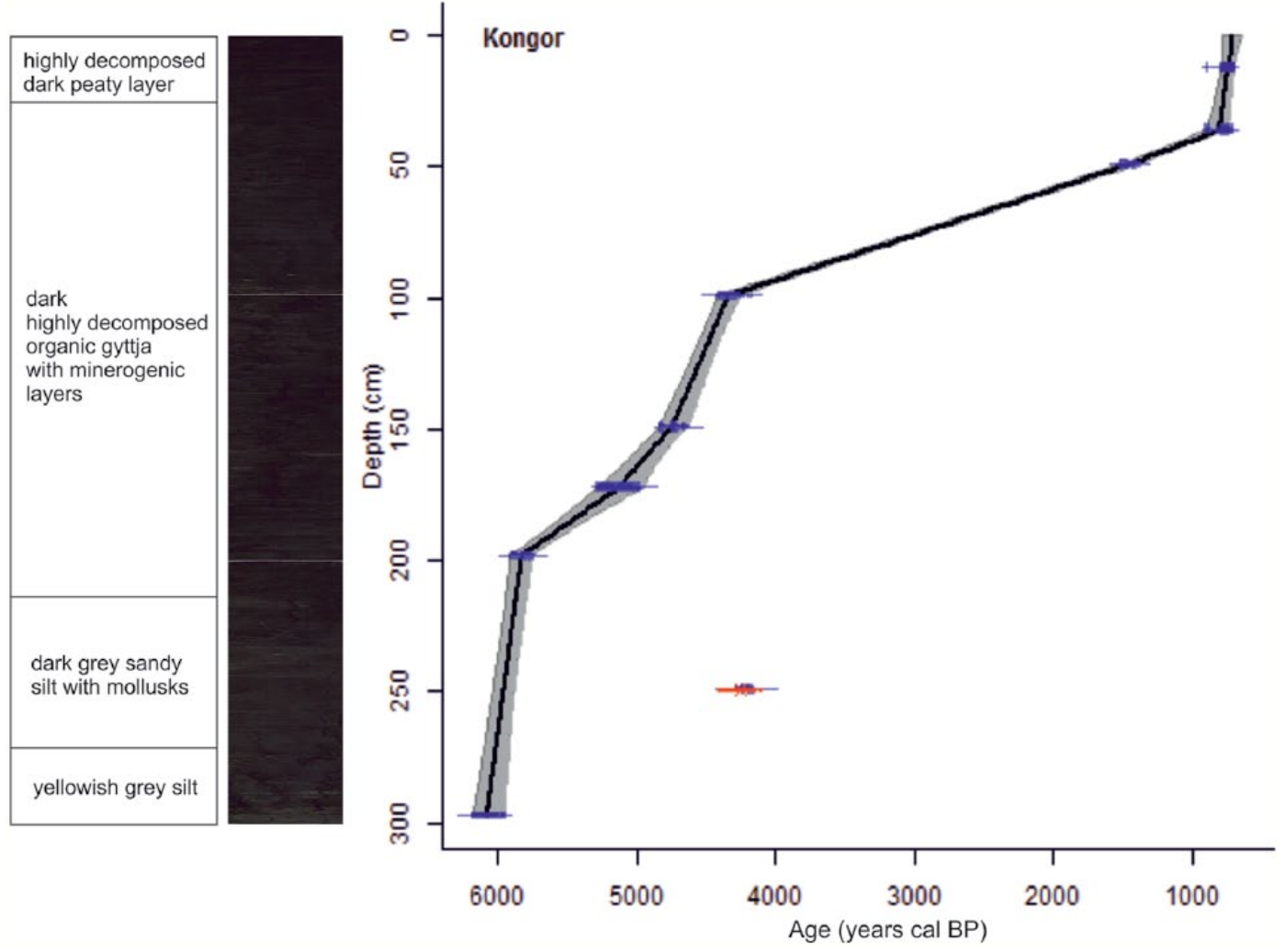

Figure 2. Age-depth model of the sediment core Kongor.

Table I. Radiocarbon dates from the Kongor core.

\begin{tabular}{|c|c|c|c|c|}
\hline Laboratory name & Core depth, $\mathrm{cm}$ & Dated material & Age ${ }^{14} \mathrm{C}$ & Calibrated age, yr BP (\% probability) \\
\hline Poz-7I968 & $12-16$ & $\begin{array}{l}\text { Charred vegetative } \\
\text { grass remains }\end{array}$ & $845 \pm 30$ & $\begin{array}{l}689-796(92.7) \\
876-883(1.2) \\
886-892(1.1)\end{array}$ \\
\hline Poz-7I969 & $36-40$ & Rubus seeds & $865 \pm 30$ & $\begin{array}{l}698-801(78.6) \\
812-827(3.3) \\
864-902(13)\end{array}$ \\
\hline Poz-6|468 & 49 & Bulk & $1550 \pm 30$ & |379-|526 (95) \\
\hline Poz-6|469 & 99 & Bulk & $3900 \pm 30$ & $4248-4417(95)$ \\
\hline Poz-6I470 & 149 & Bulk & $4200 \pm 30$ & $\begin{array}{l}4628-4639(2) \\
464 I-4763(66.3) \\
4790-4790(0 . I) \\
4797-4842(26.5)\end{array}$ \\
\hline Poz-7।97I & $172-176$ & $\begin{array}{l}\text { Charred vegetative } \\
\text { grass remains }\end{array}$ & $4465 \pm 35$ & $\begin{array}{l}4972-5144(46.8) \\
5155-5287(48.2)\end{array}$ \\
\hline Poz-6I47| & 198 & Bulk & $5085 \pm 35$ & $\begin{array}{l}5747-5834(57.3) \\
5838-5911(37.5)\end{array}$ \\
\hline Poz-6I472 & 249 & Bulk & $3830 \pm 30$ & $\begin{array}{l}4|0|-4 \mid 12(1.5) \\
4 \mid 47-4299(8 I .5) \\
43|2-43| 6(0.5) \\
4324-4355(6.2) \\
4367-4405(5.3)\end{array}$ \\
\hline Poz-6|474 & 297 & Bulk & $5285 \pm 35$ & $\begin{array}{l}5948-5967(5.2) \\
5987-6182(89.7)\end{array}$ \\
\hline
\end{tabular}

Reported age ranges in the last column are based on $2 \sigma$-range probabilities.

collection. Nomenclature and taxonomic order follow Löbl and Smetana (2003-2013). Unless otherwise stated, ecological interpretation and biogeographical data are derived from Koch (19891992), Böhme (2005) and Borumand (2000).

\section{Bulk geochemistry}

Dry bulk density (DBD, 44 samples) was determined by weighing a fixed volume of sediment in geomagnetic cubes $\left(6.8 \mathrm{~cm}^{3}\right)$ before and after freeze-drying.
Total carbon (TC) for 54 samples and total organic carbon (TOC) and calcium carbonate $\left(\mathrm{CaCO}_{3}\right)$ for 26 samples of the Kongor core were analyzed using the elemental analyzer Fisons NA1500 at CEREGE. Our analytical procedures have been described elsewhere (Soulet et al., 2011).

Bulk sediment elemental analysis was carried out at CEREGE using a multi-function X-ray fluorescence (XRF) scanner ITRAX (Cox Analytical Systems). Relative contents of potassium (K), titanium $(\mathrm{Ti})$, iron $(\mathrm{Fe})$, arsenic $(\mathrm{As})$, calcium $(\mathrm{Ca})$ and sulphur (S) were determined at $5 \mathrm{~mm}$ resolution using a $\mathrm{Cr}$ tube under 
$30 \mathrm{kV}, 55 \mathrm{~mA}$ and $15 \mathrm{~s}$ counting time. Potassium and Ti show variations of detrital fraction whereas $\mathrm{Fe} / \mathrm{Ti}$ and As reflect variations in redox conditions (Cartapanis et al., 2011). Calcium was analysed to trace carbonate and gypsum occurrence.

\section{Biomarkers}

Biomarker analysis was carried out at CEREGE using the same depths as pollen analysis ( 54 samples). About 0.5 to $1 \mathrm{~g}$ of freezedried and mortar-ground sediment was extracted with an accelerated solvent extraction system ASE350 (Thermo Scientific) using an extraction temperature of $120^{\circ} \mathrm{C}$, a pressure of 100 bars and a mixture of dichloromethane/methanol (DCM/MeOH v:v: 9:1) as extraction solvent. The total lipid extract (TLE) was separated into three fractions using glass columns filled with a glass fibre filter and $1.5 \mathrm{mg}$ of silica gel and solvents of increasing polarity (F1 $10 \mathrm{~mL}$ hexane; F2 $10 \mathrm{~mL}$ hexane/dichloromethane v:v: 1:1; F3 $10 \mathrm{~mL}$ dichloromethane/methanol v:v: 1:1). For this study, we analyzed only the aliphatic fraction containing $n$-alkanes (F1).

Gas chromatographic (GC) analyses were performed using a FID-equipped ThermoScientific Trace GC, a $60 \mathrm{~m} \times 0.25 \mathrm{~mm} \times 0.1 \mu \mathrm{m}$ non-polar fused silica column DB-5-MS (J\&W) fitted with a $2.5 \mathrm{~m} \times 0.53 \mu \mathrm{m}$ deactivated retention gap and using hydrogen as carrier gas. GC analyses oven parameters were $45-200^{\circ} \mathrm{C}$ at $17^{\circ} \mathrm{C} /$ min, $200-250^{\circ} \mathrm{C}$ at $5^{\circ} \mathrm{C} / \mathrm{min}$ and $250-300^{\circ} \mathrm{C}$ at $3^{\circ} \mathrm{C} / \mathrm{min}$. Biomarker concentrations were determined in comparison with an internal $n$-alkane (hexatriacontane) standard.

\section{Total phosphorus}

Measurement of the total phosphorus $\left(\mathrm{P}_{\text {tot }} \%\right)$ was carried out on 72 samples of the core, taken every $2-8 \mathrm{~cm}$. The procedure includes sample burning with concentrated sulphuric acid on the heater. Phosphate in the extract is determined colorimetrically employing spectrophotometer SPECOL 211 using the blue ammonium molybdate method with ascorbic acid as a reducing agent (Holliday and Gartner, 2007; Vorobiova, 1998, 2006).

\section{Magnetic susceptibility and remanent magnetization}

Rock magnetic investigations were conducted on discrete samples collected every $\sim 2 \mathrm{~cm}$ along the core. Low field magnetic susceptibility $\left(\kappa_{\mathrm{LF}}\right)$ was measured using magnetic susceptibilimeter MFK1 (Agico). Anhysteretic Remanent Magnetization (ARM) and Isothermal Remanent Magnetization (IRM) were measured using a superconducting rock magnetometer SRM 760R (2G Enterprises). The ARM was imprinted with an alternating field (AF) of $100 \mathrm{mT}$ and a direct field of $100 \mathrm{mT}$ and demagnetized at $30 \mathrm{mT}$ in line with the ARM acquisition and the AF demagnetization system of $2 \mathrm{G}$ Enterprises. IRMs (at $3 \mathrm{~T}$ and at $0.3 \mathrm{~T}$ in the opposite direction) were imprinted using a pulse magnetize MMPM9 (Magnetic Measurements Ltd). $\kappa_{\mathrm{LF}}$ estimates the contributions of ferro- (e.g. magnetite), para- (e.g. clays) and diamagnetic (e.g. calcite) phases in the magnetic signal. ARM indicates the concentration in low coercive ferromagnetic mineral such as magnetite, whereas Saturation Isothermal Remanent Magnetization (SIRM) gives the concentration in all ferromagnetic phases. For low coercive phase (magnetite), $\mathrm{ARM}_{30 \mathrm{mT}} / \mathrm{ARM}$ is a magnetic grain size indicator with high values for fine grains. Hard Isothermal Remanent Magnetization (HIRM), classically estimating haematite contribution (Robinson, 1986), is given by the calculation HIRM $\left(\mathrm{HIRM}=0.5 \times\left(\mathrm{SiRM}_{3 \mathrm{~T}}-\mathrm{IRM}_{0.3 \mathrm{~T}}\right)\right.$. S-ratio, giving the relative abundance of high coercive (haematite) and low coercive (magnetite) remanent phases, is calculated according to Bloemendal et al. (1992): S-ratio $=0.5 \times\left(1-\left[\operatorname{IRM}_{0.3 \mathrm{~T}} / \mathrm{SIRM}_{3 \mathrm{~T}}\right]\right)$. In order to define the magnetic mineralogy responsible for the remanent magnetic signal, 8 samples were subject to stepwise thermal demagnetization of the SIRM and to hysteresis measurements, the latter of which were produced using a Vibrating Sample Magnetometer MicroMag 3900 (Lake Shore Cryotronics Inc.).

\section{Results and interpretation}

\section{Age-depth model}

The radiocarbon dates of the sediment core (Table 1) provide a reliable basis for the construction of an age-depth model (Figure 2). One outlier at $249-250 \mathrm{~cm}$ is too young and has been excluded. The age-depth model reveals a high sedimentation rate in the lowest part, a decrease between 200 and $100 \mathrm{~cm}$, a further decrease between 100 and $40 \mathrm{~cm}$ and an increase from $40 \mathrm{~cm}$ to the top. According to this model, the upper part representing the last 800 years is missing, probably due to drying out and decomposition of the sediment. The ages in the results, interpretation and discussion sections are presented as weighted averages.

\section{Palynology}

In total, 123 pollen types and more than 200 NPP types were recorded. The pollen diagram was divided into three local pollen zones (LPZ) and six subzones (Figure 3).

LPZ-1 (300-228 cm, 6.1-5.9 ka) is dominated by Chenopodiaceae (16-41\%), Poaceae (10-25\%) and Artemisia (13-20\%), reflecting dry steppe conditions. Arboreal pollen (AP), dominated by Quercus and Carpinus betulus, is low (6-12\%), suggesting an open environment. Cyperaceae (8-16\%), together with monolete fern spores $(8-20 \%)$, indicates the presence of sedges and fern wetlands at the coring site, whereas Lythrum reflects eutrophic conditions (Jäger, 2011). Sparganium-type, Typha latifolia-type, Myriophyllum spicatum and Spirogyra indicate stagnant open water conditions. A wide variety of saprotrophic (e.g. Zopfiella $\mathrm{cf}$. submersa, Tetraploa aristata, Sporoschisma) and coprophilous (Podospora, Arnium, Sporormiella, Apiosordaria) fungal spores indicate decomposition processes and the presence of animals (Ellis and Ellis, 1985; Van Geel and Aptroot, 2006). The latter is also proved by eggs of the intestinal parasites Capillaria and Dicrocoelium (Lardin, 2015). Notable is a maximum of plant parasitic rusts, indicating illness in local plants.

LPZ-2 $(228-116 \mathrm{~cm}, 5.9-4.47 \mathrm{ka})$ is marked by low percentages of AP (11\%) and Poaceae (4-14\%), an increase of Artemisia (16-34\%) and Senecio-type (9\%), the dominance of Chenopodiaceae (15-39\%) and the lowest MI, suggesting more harsh and dry conditions. Local presence of Poaceae on-site during the entire record is demonstrated by the presence of charred grass remains and spores of the fungus Tetraploa aristata growing on grasses. Therefore Poaceae pollen changes might reflect a more regional than local signal (El-Moslimany, 1990). A maximum of Glomustype might indicate high soil erosion in absence of macroremains (Figure 4a). A maximum of Coniochaeta suggests increased decomposition, and a decrease in Spirogyra indicates dryer conditions in comparison to LPZ-1. LPZ-2 is divided into two subzones according to changes in PCA axis 2.

LPZ-2a $(228-188 \mathrm{~cm}, 5.9-5.55 \mathrm{ka})$ is characterized by an increased amount of Cyperaceae (16-40\%) and Sparganium-type (12-48\%) and a decrease of Lythrum (0.3-2\%) and ferns (2-4\%). Charcoal concentrations are the lowest in this subzone. There are maxima of rotatorian eggs (cf. Trichocerca cylindrica, Anuraeopsis fissa) and testate amoebae, indicating deposition of organic debris. Interesting are the presence of foraminifer linings, most likely reworked from the sediments by winds or surface run-offs, and an increase of Pseudoschizaea, a highly discussed acritarch of possibly algal nature (e.g. Scott, 1992). In fungal assemblages, a decrease of saprotrophic and saprotrophic/coprophilous types is notable, possibly due to increased water levels, leading to decreased decomposition at the site and/or further spore transport from the lake shore. 


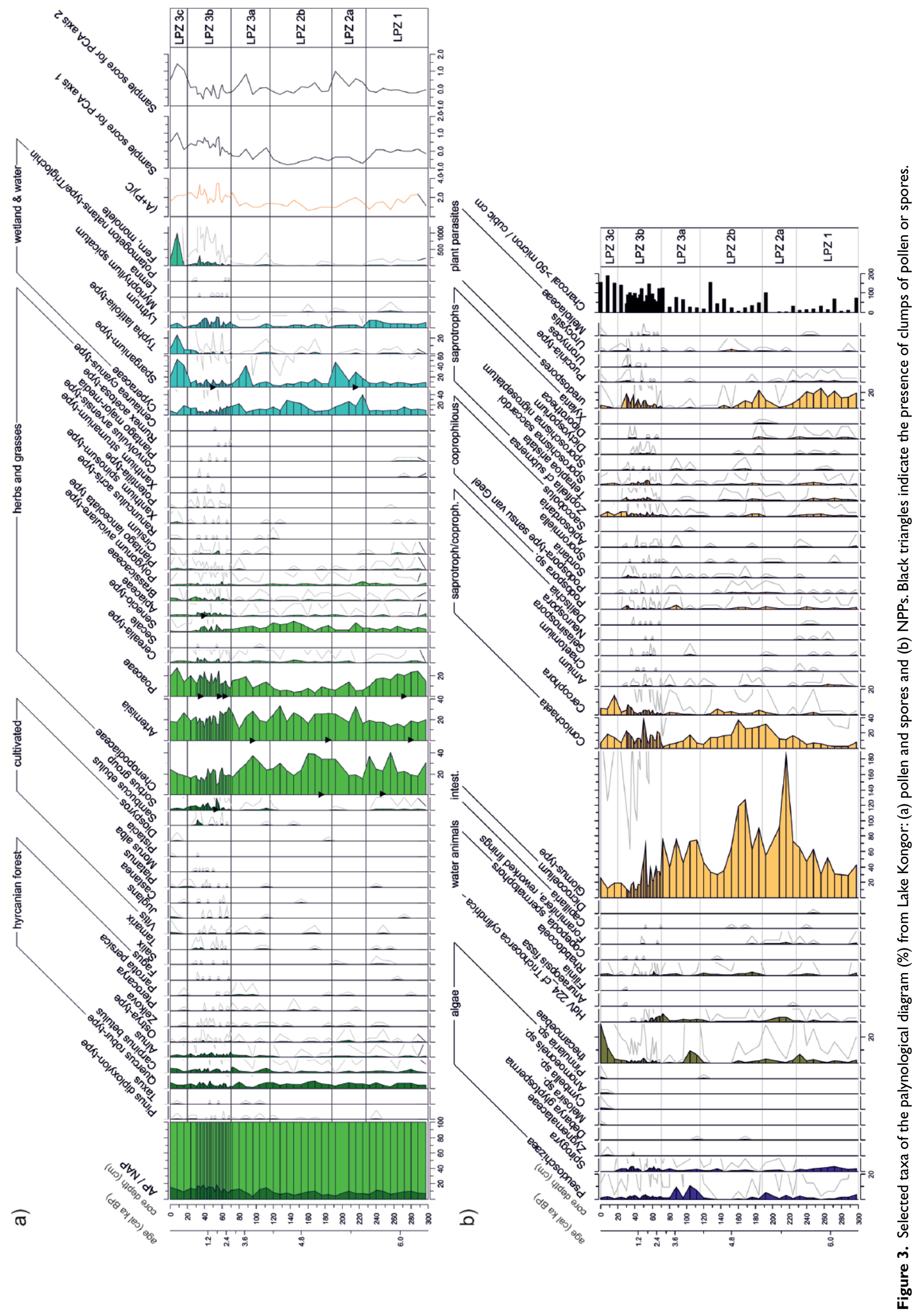




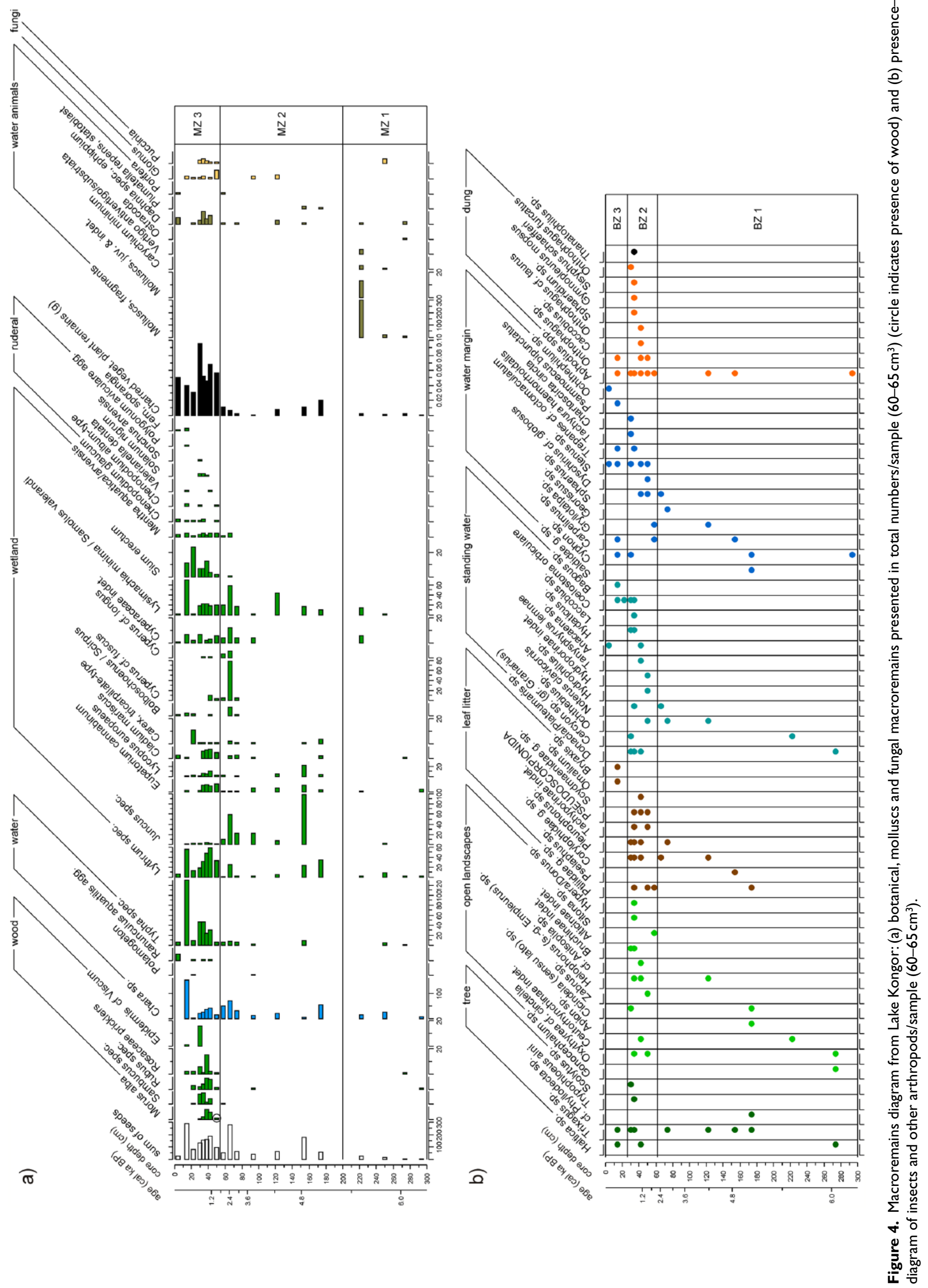


LPZ-2b (188-116 cm, $5.55-4.47 \mathrm{ka})$ is marked by an abrupt decrease in Sparganium-type (2-16\%) and Poaceae minima (4$9 \%$ ). Increased charcoal concentrations suggest occurrences of local fires. Diversity and percentages of saprotrophic taxa are high at the beginning of the subzone. The subzone is characterized by minima in Pseudoschizaea, Spirogyra, testate amoebae, and rotatorian eggs, suggesting rather dry local conditions. However, Rhabdocoela and spermatophores of copepods indicate the presence of open water, most probably temporary.

LPZ-3 $(116-0 \mathrm{~cm}, 4.47-0.7 \mathrm{ka})$ is characterized by increased percentages of Poaceae (8-28\%) and AP (4-19\%), due to an increase in conifers (Pinus, Taxus) and deciduous trees (Carpinus betulus, Alnus). The latter indicates the onset of milder conditions. Notable is the variety and amount of pollen of cultivated trees such as Vitis, Juglans, Castanea, Platanus, and Morus alba, indicating arboricultural practices, and ruderals (Sambucus ebulus and Sorbus-type, the latter probably represented by Rubus as suggested by the presence of its seeds, see section 'Macroremains'). LPZ-3 is divided into three subzones.

The main characteristic of LPZ-3a (116-71 cm, 4.47-2.72 ka) is the rapid increase of Poaceae by dominating Chenopodiaceae and an increase of MI at the end of the subzone, suggesting the spread of dry steppe due to milder conditions than in the previous zone. Sparganium-type (2-42\%), Pseudoschizaea as well as testate amoebae and cf. T. cylindrica again increase, indicating the local presence of water. Similar to subzone $2 \mathrm{a}$, the diversity and the amount of saprotrophic fungal spores remain low, possibly due to high water levels.

LPZ-3b (71-20 cm, 2.72-0.76 ka) is marked by a change in the dominant pollen taxa Artemisia (12-32\%), Poaceae (8-24\%) and Chenopodiaceae (11-25\%) and high MI, indicating dominance of Artemisia grass-steppe landscapes and mild conditions. Pollen of cultivated trees (Vitis, Juglans, Castanea, Platanus, Morus alba) and Cerealia-type (4\%) speaks for increased anthropogenic activity. Sparganium-type (3-15\%) and Cyperaceae (3-18\%) decrease, but Lemna and Potamogeton/Triglochin occur, indicating the presence of open water together with Pseudoschizaea, Spirogyra and Rhabdocoela. Lemna and Lythrum indicate eutrophic conditions (Jäger, 2011). Ferns increase, indicating the local development of fern wetlands. Organic debris deposition is suggested by testate amoebae and rotatorian eggs. Saprotrophic fungal spores increase up to $11 \%$, indicating increased decomposition on-site. Coprophilous fungal spores and eggs of Capillaria suggest the presence of dung.

LPZ-3c $(20-0 \mathrm{~cm}, 0.76-0.7 \mathrm{ka})$ is characterized by an abrupt increase in Sparganium-type (19-53\%) and Typha latifolia-type (5-24\%) together with an increase in monolete fern spores. Fern sporangia indicate that ferns were growing on-site, which is also indicated by the maximum of testate amoebae (30\%). Open water indicators (Lemna and Potamogeton) disappear; however, the presence of diatoms (Melosira, Cymbella, Anomoeoneis, Pinnularia) indicates the presence of a shallow lake. Sums of cultivated trees such as Vitis, Juglans, Castanea, Platanus, Pistacia and Diospyros reach their maxima of $3 \%$ on the core top.

\section{Botanical, zoological and fungal macroremains}

The samples contain a minimum of 55 plant taxa, including one fern, and a high variety of algal, animal and fungal remains (Figure $4 \mathrm{a}$ ). Preservation of seeds is poor. The entire record is largely dominated by seeds of water and wetland plants (Typha, Lythrum salicaria, Juncus, Eupatorium cannabinum, Lycopus europaeus, Cladium mariscus, Carex, Cyperaceae, Primulaceae), demonstrating the local presence of water and dominance of wetland vegetation. Open water is also indicated by ephippia of Daphnia sp. and oospores of Chara throughout the record. The latter speaks for clean, oligo- to mesotroph, calcareous water in the lake (Haas, 1994). Lycopus europaeus is characteristic of wetlands with nitrogen-rich soils. Cladium mariscus grows in base-rich boggy areas on calcareous soils (Jäger, 2011). The diagram was divided into three zones (MZ).

MZ-1 (300-200 cm, 6.1-5.5 ka) shows a low concentration of seeds, charred material, insects and oribatid mites, but notable is the presence of terrestrial molluscs and one ostracod. Of the molluscs, two species, namely, Carychium minimum and Vertigo antivertigo, are both characteristic of permanently wet habitats, swamps and wet meadows, usually near standing water bodies, where they live on submerged objects. They do not tolerate drought and are sensitive to the sinking of groundwater levels and drainage (Welter-Schultes, 2012).

In MZ-2 (200-54 cm, $~ 5.5-1.7 \mathrm{ka})$, molluscs and ostracods disappear, possibly due to the local surface drying, and the amount of seeds, charcoal and arthropods increase. Samples from the lower part of the zone $(176-120 \mathrm{~cm}, 5.2-4.5 \mathrm{ka})$ are characterized by enhanced amounts of charred remains, including plants and insects that argue in favour of frequent local fires. Of interest is the occurrence of statoblasts of Plumatella repens (Bryozoa), living under stagnant freshwater conditions and covering stones or submerged plants. From $74(\sim 2.9 \mathrm{ka})$ to $54 \mathrm{~cm}$ $(\sim 1.7 \mathrm{ka})$, several new wetland plant species appear such as Cyperus fuscus, Cyperus longus, Bolboschoenus/Scirpus, Sium erectum and Mentha aquatica/arvensis as well as freshwater sponges. Cyperus fuscus, a eutrophic pioneer on muddy ground, implies sinking water in summer for seed germination and long drought periods for plant development. Mentha aquatica grows in wet nutrient-rich habitats on mild acidic to calcareous, mineral or peaty soils. Sium erectum is calciphile, growing in eutrophic wetlands (Jäger, 2011).

MZ-3 $(54-0 \mathrm{~cm}, 1.7-0.7 \mathrm{ka})$ is most diverse and abundant in seeds, charcoal, arthropods and fungal remains. The most distinct feature is the presence of remains of woody species such as Morus alba, Rubus and cf. Viscum and of a variety of ruderal plants (Chenopodium glaucum, C. album, Sambucus ebulus, Valerianella dentata, Solanum nigrum, Sonchus arvensis, Polygonum aviculare agg.), indicating increased human activities close to the lake. A significant rise in the amount and diversity of charred plant remains from 52 to $48 \mathrm{~cm}(\sim 1.5 \mathrm{ka})$ indicates an increase in the frequency of local fires, roughly contemporary with the construction of the Gorgan Wall and several large compounds in its hinterland. Spores and remains of rust fungi (Puccinia) demonstrate that local plants suffered from this pathogen. The constant presence of Glomus spore bundles in the sediment possibly indicates the presence of the roots of modern plants. The upper $10 \mathrm{~cm}$ of the analysed sediment contained very low amounts of poorly preserved seeds, possibly due to recent drying out and decomposition.

\section{Insects and other arthropods}

The samples yielded a minimum of 71 taxa of Coleoptera and other orders (Figure 4b). All the beetle taxa identified in the sequence are present today in Iran (Löbl and Smetana, 20032013). The taxa are likely to have a local origin because the Kongor Lake is located in a flat area and it is not connected to any important stream. Based on insect diversity, three zones could be distinguished: beetle zone 1 (BZ-1: 292-296 to 64-68 cm, 6.1$2.4 \mathrm{ka}$ ) is marked by a low insect diversity, contrasting with the high number of taxa recorded in the overlying BZ-2 (56-60 to $28-32 \mathrm{~cm}, \sim 2-0.78 \mathrm{ka}$ ), and impoverishment in the assemblages of the uppermost BZ-3 (20-24 to $0-8 \mathrm{~cm}, 0.78-0.72 \mathrm{ka}$ ), possibly due to recent decomposition processes.

The aquatic fauna is represented by a small assemblage of water beetles including Noterus clavicornis, Coelostoma orbiculare and several other genera (Figure $4 \mathrm{~b}$ ) associated with stagnant and shallow water with abundant decaying vegetation. Leaf beetle 
Donacia/Plateumaris and two semi-aquatic weevils (Bagous and Tanysphyrus lemnae), associated with aquatic or helophytic plants, are also considered as indicators of stagnant water. Tanysphyrus lemnae feed upon the water plant Lemna, typical of stagnant and eutrophic water bodies.

Another group of insects is indicative of riparian ecosystems. Cyphon is a very common genus found on herbaceous plants, shrubs and trees close to the shores of lakes and rivers. Carpelimus and Stenus are almost exclusively associated with clayey, sandy or gravelly beaches. Georyssus and Dyschirius globosus live on sandy beaches. Trepanes octomaculatus and Tachyura haemorrhoidalis are widespread riparian ground beetles. Ochthephilum, Psammoecus bipunctatus and Sphaerius seem more associated with rotten plant accumulations near water. Non-coleopteran insects such as the small bug Chartoscirta cincta that jumps and flies readily on muddy shores of lakes, and the mole cricket Gryllotalpa that is frequently found burrowing in the clayey soil of lake shores and wetland regions, provide a picture similar with that obtained from beetles.

A small group of Coleoptera is tree dependent. Haltica tamaricis and Phyllodecta are common taxa found on riverine forest bushes and trees such as willow. Trixagus are found on the foliage of many trees but do not necessarily imply the presence of a forest nearby. The only Scolytus obtained in the sequence is very similar to European Scolytus that lives on ligneous Rosaceae such as Prunus, Malus and so on. More interesting is the occurrence of Trypophloeus alni, associated with alder and strongly suggesting the presence of a riverine forest.

A larger group of insects is associated with grasslands, steppes and open landscapes. Some taxa are phytophagous and dependent on herbaceous vegetation such as weevils Apion, Ceutorhynchinae, Sitona, Hypera/Donus, Bruchinae and the flea beetle Alticinae. The chafers (Oxythyrea, Anisoplia) are found on flowers, mainly in open environments. Other taxa are predatory, such as the tiger beetle Cicindela, a very mobile ground beetle predominantly associated with bare grounds and other open environments where it can easily detect its prey. Zabrus is always found in grasslands, in cultivated areas or in steppic environments. Subgenus Empleurus live on sandy, clayey, sunny grounds, at the base of plants, often in cultivated areas. Larvae and adults seem to be phytophagous and sometimes become a pest to turnips and wheat (Hansen, 1987). Helophorus nubilus is the only Empleurus reported from Iran today (Löbl and Smetana, 2003-2013). The darkling beetle Gonocephalum is again an open environment insect, living on dry, sandy soils with sparse vegetation, and is never found in forests.

The occurrence of several Coleoptera associated with excrements is especially interesting from a palaeoecological point of view because of their association with domestic mammals, although an association with wild animals is also possible. In the Kongor assemblages, all the dung-dependent Coleoptera are real coprophagous, feeding upon excrements either during larval stages or at the adult stage. Unfortunately, it is not possible to infer the mammal type that lived close to the Kongor site, because these dung beetles are rather euryecious in their food preference, although most are small insects that may feed upon droppings provided by moderately big animals. The exception is Sphaeridium, which is often found inside large masses of fluid excrements (e.g. cows), in which they are able to 'swim'. A single representative of a carrion beetle Thanatophilus should also be noted, suggesting that dead animals were present. The joint occurrence of dung and carrion beetles underline the presence of mammals grazing close to the depositional site during $\sim 2-0.78 \mathrm{ka}$ (BZ-2).

\section{Bulk geochemistry}

Sediment DBD is related to the proportion of its mineral and TOC content (Avnimelech et al., 2001). DBD in the Kongor core
(Figure 5) is highest $\left(0.9\right.$ to $\left.0.4 \mathrm{~g} / \mathrm{cm}^{3}\right)$ in the silty section between 300 and $228 \mathrm{~cm}(6.1-5.9 \mathrm{ka})$. Between 228 and $130 \mathrm{~cm}(5.9$ $4.6 \mathrm{ka}), \mathrm{DBD}$ values decrease to $0.3 \mathrm{~g} / \mathrm{cm}^{3}$ and increase to $0.4 \mathrm{~g} / \mathrm{cm}^{3}$ in the gyttja section between 130 and $25 \mathrm{~cm}(4.6-$ $0.77 \mathrm{ka}$ ). DBD values are low at the core top with $0.2 \mathrm{~g} / \mathrm{cm}^{3}$.

TOC are in good agreement with TC (Figure 5). Both proxies vary between $4 \%$ and $36 \%$ with lowest values in the silty section. $\mathrm{CaCO}_{3}$ content varies between $0 \%$ and $19 \%$ again with lower concentrations in the silty section. Because TOC and TC values are similar, the latter was used to normalize biomarkers (Figure 5).

$\mathrm{K}$ and Ti XRF intensity present very similar variability with high values at $300-250 \mathrm{~cm}$ and a gradual decrease towards $180 \mathrm{~cm}$ (Figure 5), suggesting the same source of these elements. After an interval of low $\mathrm{K}$ and $\mathrm{Ti}$ intensity in $180-120 \mathrm{~cm}$, the two elements have a broad peak between 120 and $40 \mathrm{~cm}$ (Figure 5). The most recent part $(40 \mathrm{~cm})$ is characterized by reduced $\mathrm{K}$ and $\mathrm{Ti}$ intensity.

Iron intensity shows a variability close to the $\mathrm{K}$ and Ti profiles, except for the interval $170-116 \mathrm{~cm}(4.47-5.1 \mathrm{ka})$ where Fe intensity is higher than the expected values from $\mathrm{K}$ and $\mathrm{Ti}$ (not shown in figure). To better illustrate the different behaviour of $\mathrm{Fe}$ in comparison to other detrital indicators, the $\mathrm{Fe} / \mathrm{Ti}$ intensity ratio is used and compared with the As profile (Figure 5). Both $\mathrm{Fe} / \mathrm{Ti}$ and As show a peak between 170 and $116 \mathrm{~cm}$. Concomitant enrichment of $\mathrm{Fe}$ and As may indicate the formation of iron sulphides such as pyrite (Croudace et al., 2006) under reducing conditions.

$\mathrm{Ca}$ and $\mathrm{S}$ profiles present similar features with sharp spikes at 295-288, 276-272, 208-204, 178-146, 110-91, 79-70 and 60$52 \mathrm{~cm}$ (Figure 5). The correlation between $\mathrm{Ca}$ and $\mathrm{S}$ suggests that the peaks are associated with the occurrence of gypsum $\left(\mathrm{CaSO}_{4}\right)$. High $\mathrm{Ca}$ and $\mathrm{S}$ intervals are located below and above the peak of $\mathrm{Fe} / \mathrm{Ti}$ and As (Figure 5). Oxidation of iron sulphides produces sulphuric acid that dissolves calcium carbonates, leading to gypsum formation. The presence of this mineral may suggest the contact of iron sulphides with atmospheric oxygen.

\section{Biomarkers: Long-chain n-alkanes (C27 to C35)}

Long-chain $n$-alkanes are important constituents of cuticular plant leaf-waxes and relatively resistant to degradation (Eglinton and Hamilton, 1963). In the Kongor sediments (Figure 5), long-chain $n$-alkanes are dominated by strong odd-numbered $n$-alkanes with a maximum at $n-29$, indicating input of terrestrial land plants (Eglinton and Hamilton, 1963). Long-chain $n$-alkane concentrations ( $\mathrm{C} 27$ to $\mathrm{C} 35)$ increase from about $10 \mu \mathrm{g} / \mathrm{g}$ in the silty section up to $38 \mu \mathrm{g} / \mathrm{g}$ in the gyttja section.

The correspondence of high TOC, TC, $n$-alkanes and $n$-alkanes/TC with low elemental $\mathrm{K}$ and Ti and magnetic susceptibility suggests that variations are partly related to dilution with aeolian material especially in the lower part of the core, and partly due to increased productivity, preservation due to wetter climate conditions and/or local presence of plants on-site.

\section{Total phosphorus}

Phosphorus is an important indicator of the anthropogenic impacts on landscapes (Golyeva et al., 2016; Holliday and Gartner, 2007). It comes into the sediment with domestic waste and household garbage, and forms extremely stable organic-mineral compounds with organic matter and ash. In the Kongor core, the total phosphorus content increases from the bottom to the top of the core and shows several maxima at 4-94, 168, 224 and $272 \mathrm{~cm}$ and a minimum at $98-160 \mathrm{~cm}$. Since natural lakes are characterized by low phosphorus content, increased concentrations of the total phosphorus suggest that the territory around the lake was regularly used by humans, most likely contributing to intensification of the pastoral pressure. 


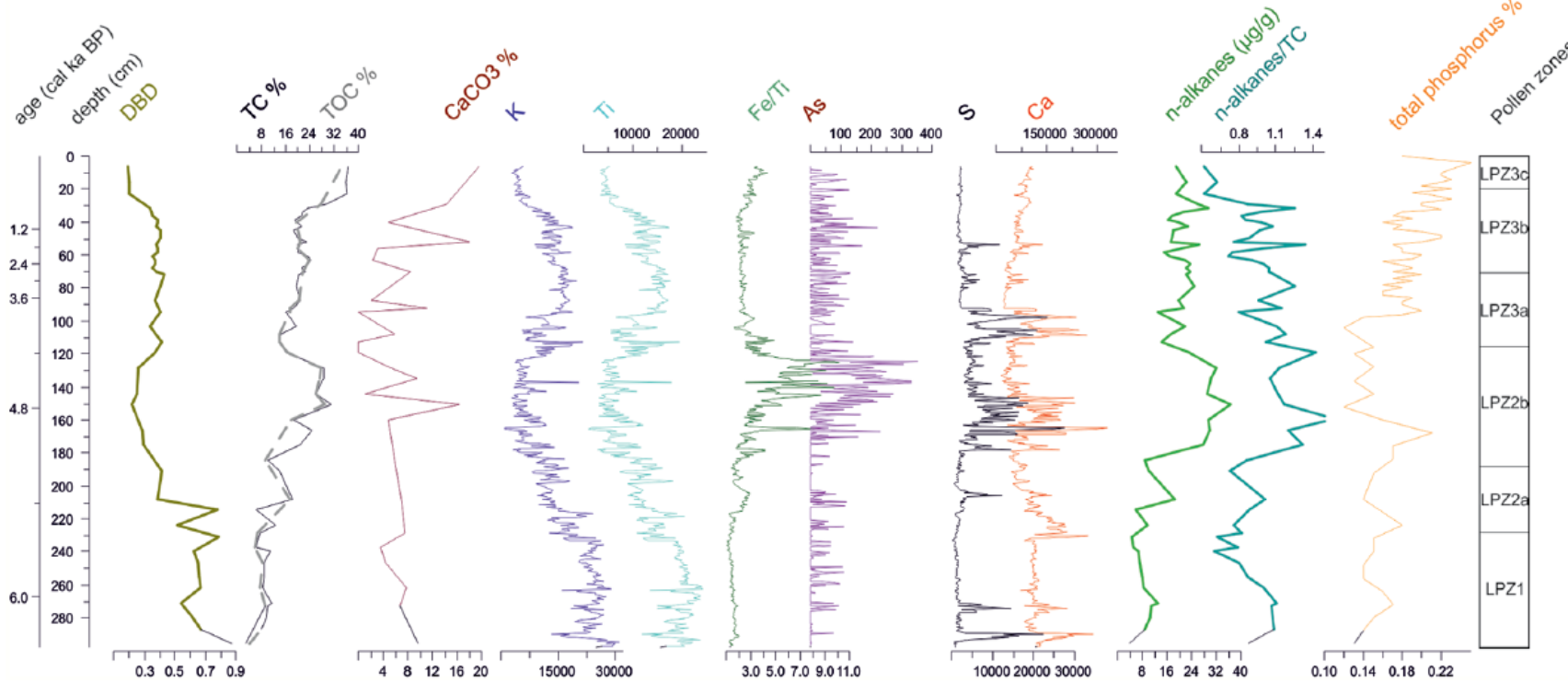

Figure 5. Bulk characteristics and biomarkers of the Kongor sediment core.

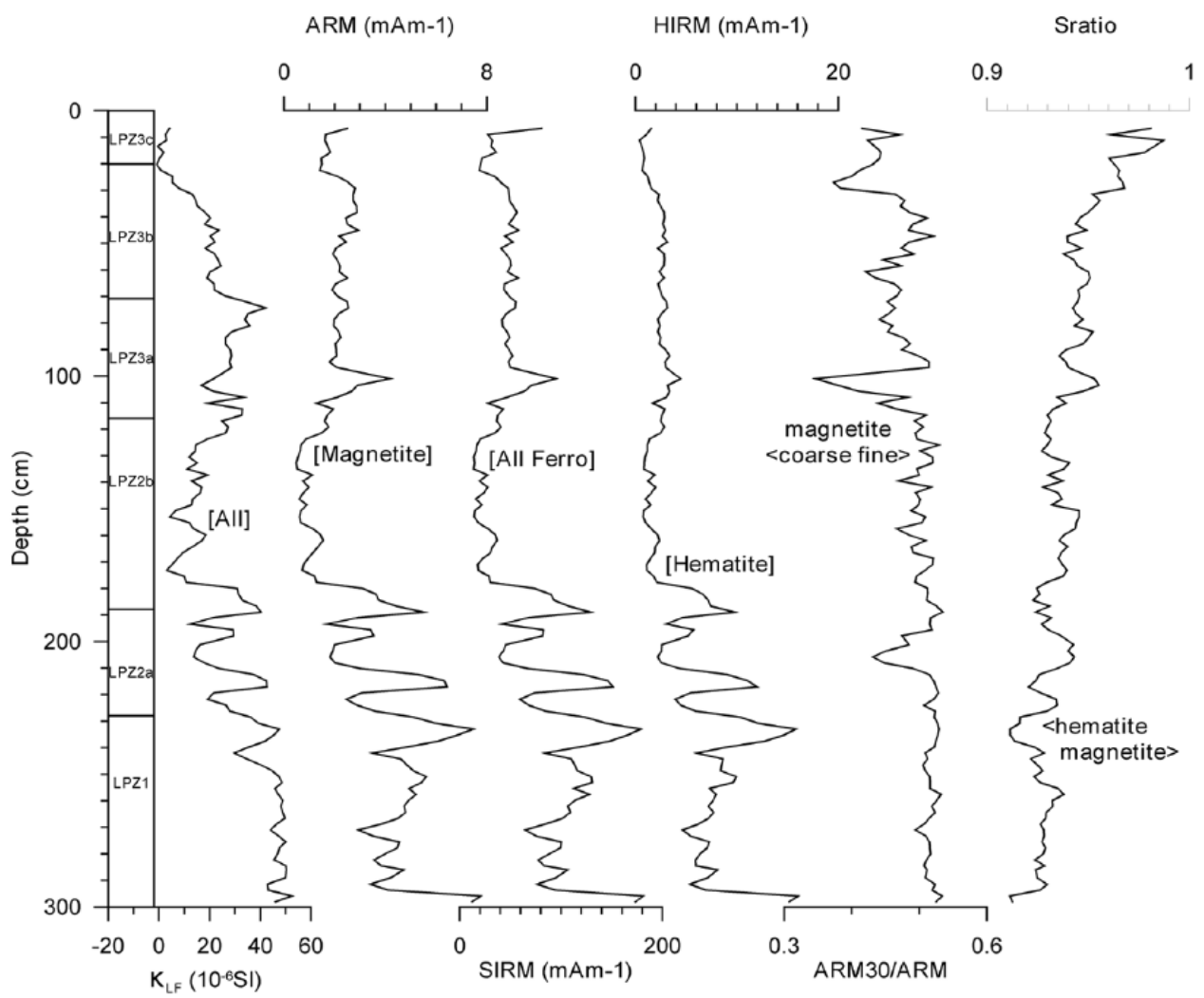

Figure 6. Downcore variation of low field magnetic susceptibility $\left(\kappa_{\mathrm{LF}}\right)$, anhysteretic remanent magnetization (ARM), saturation isothermal remanent magnetization (SIRM), hard isothermal remanent magnetization (HIRM), ARM30/ARM and S-ratio. The significance of the parameters in terms of concentration or relative abundance is noted in the figure. The pollen zones are also identified.

\section{Environmental magnetism}

The magnetic susceptibility (Figure 6) ranges from almost $60 \times 10^{-6}$ SI at the base of the sedimentary column to negative values at its top. A strong decrease is observed at $220 \mathrm{~cm}$ and a slight re-increase of the values at $\sim 120 \mathrm{~cm}$. Remanent parameters of concentration in low coercive minerals (ARM), in high coercive minerals (HIRM) and in all ferromagnetic minerals (SIRM) show the same pattern. The S-ratio shows a constant drift from 0.9 to almost 1 from the bottom to the top core. The ARM30/ARM is quite constant with changes in ion restricted levels towards coarse grains at around $210 \mathrm{~cm}$
$(5.85 \mathrm{ka}), 105 \mathrm{~cm}(4.39 \mathrm{ka})$ and at the top core $(0.7 \mathrm{ka})$. The determination of magnetic mineralogy, based on stepwise thermal demagnetization of SIRM, shows progressive unblocking temperatures, with a signal close to zero obtained at $590^{\circ} \mathrm{C}$ (Curie temperature of magnetite) for most of the samples. For two samples, a slight signal remains at higher temperatures showing the presence of haematite. The hysteresis parameters fall in the pseudo single domain, arguing in favour of magnetite few micrometres in size as the main carrier of the remanent magnetization, mixing of different grain sizes also being possible (Dunlop, 2002). 


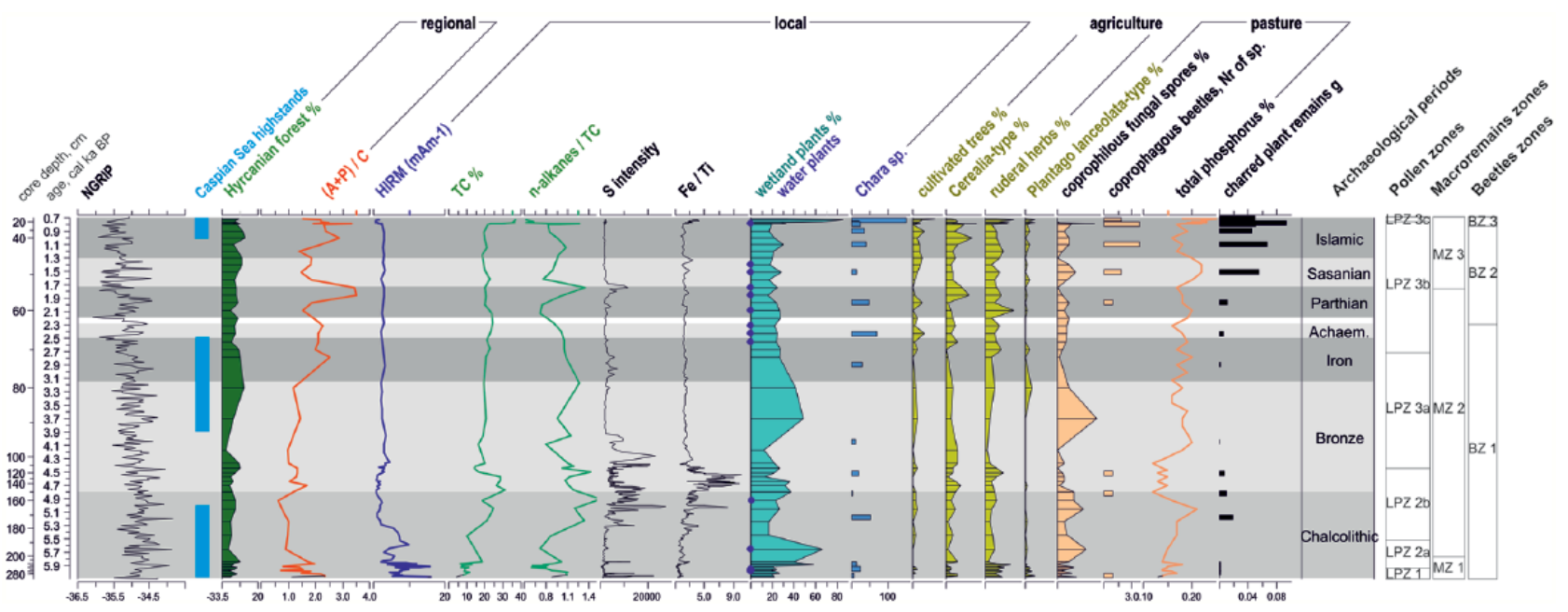

Figure 7. Summary diagram from the Kongor Lake, combining Northern Hemisphere (NGRIP from Svensson et al., 2008), Caspian Sea highstands (Rychagov, 1997) in comparison to regional, local and anthropogenic (agriculture, pasture) signals from Kongor core. Chronology of the archaeological periods is based on Deshayes and Boucharlat (1987), Roustaei et al. (2015), Sauer et al. (20I3) and Thornton (20I3). Achaem $=$ Achaemenid empire; Moisture index $(\mathrm{A}+\mathrm{P}) / \mathrm{C}=($ Artemisia + Poaceae $) /$ Chenopodiaceae .

According to the magnetic mineralogy, magnetites of few micrometres dominate the magnetic signal, with haematites also being documented. The S-ratio, sensitive to diagenesis such as magnetite dissolution (Demory et al., 2005), is not affected by strong and steep variations, arguing that the change in magnetic concentration displayed by magnetic parameters is due to detrital change. The major change is a strong decrease at the beginning of the LPZ-2b probably related to a decomposition of a detrital input. A drop in ARM30/ARM, linked to an increase in concentration parameters, could be related to a short detrital event bringing coarse magnetites. Diagenetic features can be punctually observed in the low ARM30/ARM values as a decrease of the relative abundance of fine magnetite grains at $210 \mathrm{~cm}$, that is, $30 \mathrm{~cm}$ below the major detrital input decrease. Another diagenetic feature is illustrated by the iron mobility observed in LPZ-2b by $\mathrm{XRF}$. This feature is not revealed by the magnetic signal due to the low concentration in magnetic particles in this interval. Diagenetic features are linked to oxidizing processes responsible for iron mobility and probably for magnetite dissolution.

\section{Discussion}

\section{Local development of the site}

The site resembled a calcareous marsh with stagnant shallow water and meso- to eutrophic conditions evidenced by the constant presence of Chara oospores, Daphnia ephippia and water beetles throughout the core. The banks were formed of gentle slopes with muddy, clayey or sandy substrates. The surrounding vegetation consisted of typical calcareous nutrient-rich wetland plants such as Typha, Lythrum, Eupatorium cannabinum, Cladium mariscus, Juncus, Cyperaceae and ferns. Accumulations of leaf litter and other decaying plant debris were present.

Several proxies indicate changing hydrological conditions of the marsh through time (Figure 7). During the period 6.1-5.9 ka, a shallow permanent lake was present, indicated by remains of ostracods, molluscs, pollen of M. spicatum and algae (Spirogyra) (Figure 3). The permanent water body formed an efficient trap for aeolian particles, explaining high dust input causing a very high sedimentation rate, high DBD, $\mathrm{K}$ and Ti contents and $\kappa_{\mathrm{LF}}$ in accordance with low TOC, $n$-alkanes and few plant and beetle remains during this period. Long-chain $n$-alkanes and TOC-TC concentrations are relatively low and homogenous due to dilution by dust-forming minerals transported from Central Asia to the Golestan province (Asadi et al., 2013; Okhravi and Amini,
2001). DBD reflects this process with high values in the minerogenic section due to increased mineral content and lower values in the upper organic-rich section of the core.

From 5.9 to $5.55 \mathrm{ka}$, less precipitation and higher evaporation might have led to occasional summer drying of the lake, indicated by the disappearance of molluscs and ostracods. A drying event at $\sim 5.85 \mathrm{ka}$ is evidenced by gypsum formation and a short detrital event bringing coarse magnetites.

More frequent local fires are documented between 5.55 and $3.2 \mathrm{ka}$ by increased values of microcharcoal and charred plant and insect remains. Geochemical analysis indicates more regular droughts between 5.3 and $4 \mathrm{ka}$, leading to iron sulphide formation, its oxidation and following gypsum precipitation. Seasonal drought is probably responsible for a decomposition of the detrital input marked by diagenetic features observed in rock magnetic properties and in the iron mobility, related to oxidation processes. Such a longer dry season may indicate an increase in 'mediterraneity' of the climate in eastern Hyrcanian region at this time. It is possible to assume that plants started growing on the core site at this time. Organic accumulation with rather high decomposition rates is evidenced by lower DBD values, increased TOC, high amounts of saprotrophic fungal spores and a decrease of the sedimentation rate. $N$-alkanes normalized to TC (Figure 5) suggest that the increase in $n$-alkane concentration is only partly due to dilution with possible dust supply and probably due to the local development of organic-rich layers.

From $\sim 2.8 \mathrm{ka}$, the hydrological conditions on-site indicate a change to an increased water supply. The presence of open water is evidenced by pollen of Lemna, Potamogeton natanstype/Triglochin, Typha latifolia-type as well as by the presence of freshwater sponges. The development of riparian forests near the site is evidenced by the increase of Salix and Tamarix pollen in combination with riparian beetles. The uppermost $20 \mathrm{~cm}$ of the core, covering $\sim 600 \mathrm{yrs}(\sim 0.76-0.7 \mathrm{ka})$, is presented by peaty sediments (TOC $>35 \%$, DBD $=0.2 \mathrm{~g} / \mathrm{cm}^{3}$ ) composed by ferns, indicated by abundant fern spores and fern sporangia.

\section{Regional environment and climate}

As a whole, the pollen and Coleopteran assemblages from Kongor provide a coherent picture of the landscape that prevailed around the site throughout the period from 6.1 to $0.7 \mathrm{ka}$. Hyrcanian forest was not growing on the Gorgan plain in the vicinity of the core site and was most probably no closer than it is today (Figure 7). The 
absence of typical Hyrcanian forest trees is clearly indicated by the scarcity of tree-dependent insects. Many Coleoptera adapted to grasslands and open environments confirm this indication, along with coprophilous beetles suggesting that the site of Kongor was frequented by large mammals, possibly domestic cattle. We suggest here that the landscape was largely open but the shores of the water body were probably ringed by a riverine forest gallery. Such a treeless landscape can be attributed to dry climatic conditions or to strong agro-pastoralism (e.g. Ponel et al., 2013). In the case of the Kongor record, climate might have been the main cause of the dominance of open landscapes, varying from moist to dry steppe and possibly desert. Apparently, it was too arid to support the growth of trees. An intensified anthropogenic impact on the vegetation and environment is visible for the last $2.7 \mathrm{ka}$ and especially between $\sim 2$ and $0.76 \mathrm{ka}$ (see section 'Humans and the landscape'). In comparison to the TM record (Leroy et al., 2013a), CP05 and the combined sequences of cores CP14 and GS05 from the southern Caspian Sea (Leroy et al., 2007, 2013b), the Kongor core shows a clear transition of desert/dry steppe/wet steppe vegetation types, but it has a less pronounced Hyrcanian forest signal possibly due to a much smaller catchment area.

The local development of the Lake Kongor reveals fluctuating water levels, which can be explained at least partly by change of climatic conditions influencing precipitation and evaporation rates as well as the groundwater level. The persistence of water in the lake would be related to a high water table during humid periods, whereas dry periods would imply a lower water table, the lake being therefore affected by the seasonal water table. The driest local periods at $\sim 5.85 \mathrm{ka}$, reconstructed from the geochemical and magnetic studies, correspond very well to the regional dry period with the dominance of dry steppe to desert conditions between 5.9 and $3.9 \mathrm{ka}$. Compared to the SW part of the Caspian Sea, the dry period in the eastern Gorgan region between 5.9 and $2.7 \mathrm{ka}$ correlates well with a drought event occurring between 4.55 and $2.8 \mathrm{ka}$ in the Neor Lake and is attributed to a stronger Siberian High (Sharifi et al., 2015). The first change to wetter conditions at Kongor occurred after $4 \mathrm{ka}$ with the spread of Artemisia-steppe, and since $2.7 \mathrm{ka}$, Artemisia-grass-steppe. In this respect, regular occurrence of Pinus, which does not grow naturally in modern Iran, and of Fagus since $2.7 \mathrm{ka}$ might indicate long-distance transport from the west. This might point out an establishment of northwest and west-dominated winds or strong storms in May-June during the flowering season, typical for the present day (Terziev, 1992). On the Northern Hemisphere scale, a climatic cooling trend is suggested by the NGRIP record from $\sim 2.9$ to $2.5 \mathrm{ka}$ (Figure 7), and reflected in the establishment of cool and humid conditions at $\sim 2.6 \mathrm{ka}$ in the central Hyrcanian forests (Ramezani et al., 2016) and a significant highstand of the Caspian Sea (Kroonenberg et al., 2007).

The Caspian Sea experienced several highstands and lowstands in the Holocene. Its level oscillated between -21 and $-31 \mathrm{~m}$ since the mid-Holocene (Rychagov, 1997). The surface gradient in the SE part of the Caspian Sea varies between 0.0007 and 0.0009 . A $10 \mathrm{~m}$ sea level rise or fall could inundate or reclaim $10-15 \mathrm{~km}$ horizontally. A vast area can be revealed in the case of a sharp sea level fall, which then acts as a local dust source, influencing the environment of a significant area of the Caspian Sea lowlands (Haghani et al., 2015; Kakroodi et al., 2012, 2015; Leroy et al., 2013a; Naderi Beni et al., 2013; Ramezani et al., 2016). Environmental records from Kongor Lake are in general agreement with reconstructions from the TM record in Gomishan lagoon (Leroy et al. 2013a). Pollen zone TM4 (barren in palynomorphs due to a lowstand) and the presence of gypsum at 4-3.9 ka suggests a lowstand of the sea lasting until $3.5 \mathrm{ka}$ with the lowest levels being reached at $3.9 \mathrm{ka}$ and development of Artemisiasteppe in the region later on. Furthermore, dry conditions between 5.9 and $3.9 \mathrm{ka}$ in the Gorgan Plain correspond to the Caspian Sea level fall of Makhachkala around 5.5-3.5 ka, recorded in many sites (e.g. Lahijani et al., 2009; Leroy et al., 2013a, 2013b; Rychagov, 1997), whereas subsequent wetter climate conditions suggested in the Kongor record are represented by highstands in the Caspian Sea.

\section{Humans and the landscape}

Most of the known prehistoric sites in the Gorgan Plain are concentrated south of the Gorgan River, which receives higher rainfall than the north. Significant colonization of the more arid steppe region north of the Gorgan River appears to have occurred in the Iron Age (around or after the 8th century BC) but ends before the construction of the Gorgan Wall in the 5th or early 6th century AD. An increase in the number of settlements in the more arid northern part of the plain correlates well with the start of the moistest conditions in the region at $2.8 \mathrm{ka}$. However, the decrease in settlement in the north during the Sasanian period (ca. 3rd-7th centuries $\mathrm{AD}$ ) is more likely due to socio-political, rather than climatic reasons since traces of aridification are not visible in the Kongor or TM cores (Leroy et al., 2013a) in spite of the regression of the Caspian Sea at $1.5 \mathrm{ka}$ (Rychagov, 1997). The construction of the Gorgan Wall (5th/early 6th century), in response to the threat posed by the northern nomadic groups, focused Sasanian activity in the south (i.e. behind the wall). A significant investment in canal irrigation for agriculture in the southern part of the Gorgan Plain (Rahimi-Laridjani, 1988) was likely supported by the security provided by the Gorgan Wall and associated military infrastructure.

Considering the human impact on the environment, the Kongor pollen record shows a very slight increase of Cerealia-type and accompanying indicators from $\sim 2.6 \mathrm{ka}$ (Figure 7 ). The molecular compound miliacin has been shown to be a valuable marker for broomcorn millet (Panicum miliaceum) cultivation (e.g. Jacob et al., 2009). For the Kongor sediments, preliminary analyses at CEREGE indicate the presence of miliacin from 2.6 to $0.8 \mathrm{ka}$. Moreover, increased human impact includes the propagation of cultivated trees such as walnut, chestnut and grapevine for fruit, the white mulberry tree possibly for silk production or the plane tree for creating shade. The cultivation of grapevine is also evidenced from ongoing excavations at the Sari Su River close to Fort 2 (unpubl.), whereas walnut and plane woods were found during the excavations in the western part of the Gorgan Plain (Poole and Gale, 2013). An increase of Juglans and Vitis since the period of the Persian empires (from the Achaemenid through Sasanian periods) is evidenced by other pollen records from Iran (Djamali et al., 2009b, 2011b; Leroy et al., 2013a; Ramezani et al., 2016; Shumilovskikh et al., submitted; Talebi et al., 2015), showing the massive impact of the Persian empires on the vegetation and landscapes in the entire region. An increase in charred plant remains at $\sim 1.5 \mathrm{ka}$ (Figure $4 \mathrm{a}$ ) is contemporary with the construction of the Gorgan Wall and suggests dense occupation in Sasanian times. The next maximum of anthropogenic indicators occurred around the turn of the millennium when the city of Jurjan flourished and the Gonbad Tower was built.

A slight decrease of Hyrcanian forest indicators during the Persian empires implies active deforestation. The Pterocarya decrease detected in central Hyrcanian forests (Ramezani et al., 2016) and Gomishan lagoon (Leroy et al., 2013a) is not apparent in the Kongor record, which is located in dryer conditions much further east and has therefore a very weak signal similar to surface samples from the Golestan National Park (Djamali et al., 2009a).

In the vicinity of the Kongor Lake, increased concentrations of total phosphorus reveal weak periods of human occupation at the end of the Neolithic (Figure 7). Most possibly at the beginning of the dry period, people were attracted to water of the Kongor Lake. Therefore, increased charcoal concentration at this time could 
have anthropogenic causes. After a phase in which the local area appears to not have been settled, an increase in human activities is suggested from the middle Bronze Age and increased further during the Iron Age with maxima during the later Sasanian period and late Middle Ages.

The presence of wild or domestic animals can be traced from the beginning of the record by the occurrence of Plantago lanceolata-type pollen, coprophilous fungal spores and beetles, and total phosphorus; however, intensified pastoral activities can be suggested for the last $2 \mathrm{ka}$. The faunal assemblages from excavated sites on the plain support the interpretation that the plain has long been used for grazing, with sheep and goat dominating the faunal record (Mashkour et al., 2013).

\section{Conclusions}

The sediment core from Kongor Lake, located in the eastern Gorgan Plain (NE Iran), provides climatic, environmental and vegetation records between 6.1 and $0.76 \mathrm{ka}$. The landscapes were open during the entire period under consideration, and there is evidence for a dry period lasting from 5.9 to $3.9 \mathrm{ka}$ with increased humidity afterwards, corresponding to the Northern Hemisphere-climatic and Caspian Sea-level changes. The spread of Artemisia grasssteppe landscapes since $2.8 \mathrm{ka}$ coincide with increased settlement north of the Gorgan River, suggesting that climate amelioration might have played an important role in increased settlement activity during the Iron Age. Anthropogenic influence on vegetation can be traced over the last $2.7 \mathrm{ka}$ with a maximum between 2 and $0.76 \mathrm{ka}$, indicating that the Parthian and Sasanian empires had a major influence on landscape evolution, a trend which continued into the subsequent Islamic era up until the early second millennium, when the city of Jurjan was enjoying great prosperity.

\section{Acknowledgements}

We are grateful to T. Reiser and F. Schlütz for their kind help with the identification of botanical macroremains and molluscs. We greatly appreciate the two anonymous reviewers for their critical reading and improving of the manuscript.

\section{Funding}

The study was supported by the European Research Council project PERSIA (grant 295375) and partially by D.I. Mendeleev Scientific Fund Program of Tomsk State University and RFBR (16-35-60083 and 16-36-00293).

\section{References}

Abbasi G (2011) Final Report of the Archaeological Excavations at Narges Tappeh, Gorgan Plain, Iran. Gorgan: Golestan Cultural and Heritage Organization and Golestan Higher Education Institute (in Persian).

Akhani H, Djamali M, Ghorbanalizadeh A et al. (2010) Plant biodiversity of Hyrcanian relict forests, $\mathrm{N}$ Iran: An overview of the flora, vegetation, palaeoecology and conservation. Pakistan Journal of Botany 42: 231-258.

Arne TJ (1945) Excavations at Shah Tepe, Iran. Stockholm, Göteborg: Elanders Boktryckeri Aktiebolag.

Asadi S, Moore F and Keshavarzi B (2013) The nature and provenance of Golestan loess deposits in northeastern Iran. Geological Journal 48: 646-660.

Avnimelech Y, Ritvo G, Meijer LE et al. (2001) Water content, organic carbon and dry bulk density in flooded sediments. Aquacultural Engineering 25: 25-33.

Beug H-J (2004) Leitfaden der Pollenbestimmung fur Mitteleuropa und angrenzende Gebiete. Munich: Verlag Dr Friedrich Pfeil.

Blaauw M (2010) Methods and code for 'classical' age-modelling of radiocarbon sequences. Quaternary Geochronology 5: $512-518$.
Bloemendal J, King JW, Hall FR et al. (1992) Rock magnetism of Late Neogene and Pleistocene deep-sea sediments relationship to sediment source, diagenetic processes and sediment lithology. Journal of Geophysical Research 97(b4): 4361- 4375.

Böhme J (2005) Die Käfer Mitteleuropas. Band K: Katalog (Faunistische Übersicht). München: Springer.

Borumand H (2000) Insects of Iran: The List of Coleoptera in the Insect Collection of Plant Pests \& Diseases Research Institute. Chrysomeloidea: Fam. (160). Coleoptera (XXIV). Chrysomelidae. Teheran: Ministry of Agriculture, Agricultural Research, Education \& Extension Organization, Plant Pests \& Diseases Research Institute, Insect Taxonomy Research Department (Publ. No 4).

Boucharlat R and Lecomte O (1987) Fouilles de Tureng Tepe. Les périodes sassanides et islamiques. Paris: Éditions Recherche sur les Civilisations.

Cartapanis O, Tachikawa K and Bard E (2011) Northeastern Pacific oxygen minimum zone variability over the past $70 \mathrm{kyr}$ : Impact of biological production and oceanic ventilation. Paleoceanography 26(4): PA4208.

Cleuziou S (1985) L'Âge du Fer à Tureng Tepe (Iran) et ses relations avec l'Asie centrale. In: L'Archéologie de la Bactriane ancienne (Actes du colloque franco-soviétique, Dushambe (URSS), 27 Octobre-3 Novembre 1982. Paris: Editions du Centre national de la recherche scientifique, pp. 175-185.

Crawford V (1963) Beside the Kara Su. The Metropolitan Museum of Art Bulletin, New Series 21(8): 263-273.

Croudace IW, Rindby A and Rothwell RG (2006) ITRAX: Description and evaluation of a new multi-function X-ray core scanner. In: Rothwell RG (ed.) New Techniques in Sediment Core Analysis. London: Geological Society Special Publications, pp. 51-63.

De Morgan J (1902) La délégation en Perse du Ministère de l'instruction publique 1897 à 1902. Paris: Ernest Leroux.

Demory F, Oberhänsli H, Nowaczyk NR et al. (2005) Detrital input and early diagenesis in sediments from Lake Baikal revealed by rock magnetism. Global and Planetary Change 46: $145-166$.

Deshayes J (1975) Les fouilles récentes de Tureng Tépé: la terrasse haute de la fin du IIIe millénaire. Comptes rendus des séances de l'Académie des Inscriptions et Belles-Lettres, $119 \mathrm{e}$ année 4: 522-530.

Deshayes J and Boucharlat R (1987) Fouilles de Tureng Tepe. Paris: Editions Recherche sur les Civilisations.

Djamali M, de Beaulieu J-L, Campagne P et al. (2009a) Modern pollen rain-vegetation relationships along a forest-steppe transect in the Golestan National Park, NE Iran. Review of Palaeobotany and Palynology 153: 272-281.

Djamali M, de Beaulieu J-L, Miller NF et al. (2009b) Vegetation history of the SE section of Zagros Mountains during the last five millenia; a pollen record from Maharlou Lake, Fars Province, Iran. Vegetation History and Archaeobotany 18: 123-136.

Djamali M, Akhani H, Khoshravesh R et al. (2011a) Application of the Global Bioclimatic Classification to Iran: Implications for understanding the modern vegetation and biogeography. Ecologia Mediterranea 37: 91-114.

Djamali M, Miller NF, Ramezani E et al. (2011b) Notes on arboricultural and agricultural practices in ancient Iran based on new pollen evidence. Paléorient 36: 175-188.

Djamali M, Jones MD, Migliore J et al. (2015) Olive cultivation in the heart of the Persian Achaemenid Empire: New insights to agricultural practices and environmental changes reflected in a late-Holocene pollen record from Lake Parishan, SW Iran. Vegetation History and Archaeobotany. Epub ahead of print 13 August. DOI: 10.1007/s00334-015-0545-8.

Dunlop DJ (2002) Theory and application of the Day plot (Mrs/Ms versus $\mathrm{Hcr} / \mathrm{Hc})$. 1. Theoretical curves and tests 
using titanomagnetite data. Journal of Geophysical Research 107: EPM 4-1-EPM 4-22.

Eglinton G and Hamilton RJ (1963) The distribution of alkanes. In: Swain T (ed.) Chemical Plant Taxonomy. New York: Academic Press, pp. 187-218.

Ellis MB and Ellis JP (1985) Microfungi on Land Plants. Slough: The Richmond Publishing Co. Ltd.

El-Moslimany AP (1990) Ecological significance of common nonarboreal pollen: Examples from drylands of the Middle East. Review of Palaeobotany and Palynology 64: 343-350.

Gerasimov IP (1964) Fiziko-Geographicheskiy Atlas Mira. Moscow: AN SSSR (in Russian).

Golyeva A, Zazovskaia E and Turova I (2016) Properties and advances in classification in ancient deeply transformed manmade soils (ancient cultural layers) by the example of Early Iron Age sites in Central Russia. Catena 137: 605-610.

Haas JN (1994) First identification key for charophyte oospores from central Europe. European Journal of Phycology 29: 227-235.

Haghani S, Leroy SAG, Khdir S et al. (2015) An early 'Little Ice Age' brackish water invasion along the south coast of the Caspian Sea (sediment of Langarud wetland) and its wider impacts on environment and people. The Holocene. Epub ahead of print 24 July. DOI: 10.1177/0959683615596835.

Hansen M (1987) The Hydrophiloidea (Coleoptera) of Fennoscandia and Denmark, Fauna Entomologica Scandinavica 18. Leiden, Copenhagen: Brill, Scandinavian Science Press.

Herzschuh U (2007) Reliability of pollen ratios for environmental reconstructions of the Tibetan Plateau. Journal of Biogeography 34: 1265-1273.

Holliday VT and Gartner WG (2007) Methods of soil P analysis in archaeology. Journal of Archaeological Science 34: 301-333.

Jacob J, Disnar J-R, Arnaud F et al. (2009) Impacts of new agriculture practices on soil erosion during the Bronze Age in the French Alps. The Holocene 19: 141-249.

Jäger EJ (2011) Exkursionsflora von Deutschland. Gefäßpflanzen: Grundband. Heidelberg: Springer.

Kakroodi AA, Kroonenberg SB, Hoogendoorn RM et al. (2012) Rapid Holocene sea-level changes along the Iranian Caspian coast. Quaternary International 263: 93-103.

Kakroodi AA, Leroy SAG, Kroonenberg SB et al. (2015) Late Pleistocene and Holocene sea-level change and coastal paleoenvironment evolution along the Iranian Caspian shore. Marine Geology 361: 111-125.

Kehl M (2009) Quaternary climate change in Iran - The state of knowledge. Erdkunde 63: 1-17.

Khalili A (1973) Precipitation patterns of Central Elburz. Theoretical \& Applied Climatology 21: 215-232.

Kiani MY (1982) Parthian Sites in Hyrcania: The Gurgan Plain. Berlin: Reimer.

Koch K (1989-1992) Die Käfer Mitteleuropas, Ökologie 1, 2 \& 3. Krefeld: Goecke \& Evers.

Kohl P (1984) Central Asia: Palaeolithic Beginnings to the Iron Age. Paris: Éditions Recherche sur les Civilisations.

Kroonenberg SB, Abdurakhmanov GM, Badyukova EN et al. (2007) Solar-forced 2600 BP and Little Ice Age highstands of the Caspian Sea. Quaternary International 173-174: 137-143.

Lahijani HAK and Tavakoli V (2012) Identifying provenance of South Caspian coastal sediments using mineral distribution pattern. Quaternary International 261: 128-137.

Lahijani HAK, Rahimpour-Bonab H, Tavakoli V et al. (2009) Evidence for late-Holocene highstands in Central GuilanEast Mazanderan, South Caspian coast, Iran. Quaternary International 197: 55-71.

Lardin C (2015) Helminths: Handbook for Identification and Counting of Parasitic Helminths Eggs in Urban Wastewater. London: IWA Publishing.
Leroy SAG, Kakroodi AA, Kroonenberg S et al. (2013a) Holocene vegetation history and sea level changes in the SE corner of the Caspian Sea: Relevance to SW Asia climate. Quaternary Science Reviews 70: 28-47.

Leroy SAG, Lahijani HK, Djamali M et al. (2011) Late Little Ice Age palaeoenvironmental records from the Anzali and Amirkola Lagoons (south Caspian Sea): Vegetation and sea level changes. Palaeogeography, Palaeoclimatology, Palaeoecology 302: 415-434.

Leroy SAG, Marret F, Gibert E et al. (2007) River inflow and salinity changes in the Caspian Sea during the last 5500 years. Quaternary Science Reviews 26: 3359-3383.

Leroy SAG, Tudryn A, Chalié F et al. (2013b) From the Allerød to the mid-Holocene: Palynological evidence from the south basin of the Caspian Sea. Quaternary Science Reviews 78: 77-97.

Löbl I and Smetana A (2003-2013) Catalogue of Palaearctic Coleoptera, vols. 1-8. Stenstrup: Apollo Books \& Leiden: Brill.

Mashkour M, Radu V and Thomas R (2013) Animal bones. In: Sauer E, Omrani Rekavandi H, Wilkinson TJ et al. (eds) Persia's Imperial Power in Late Antiquity: The Great Wall of Gorgan and Frontier Landscapes of Sasanian Iran. Oxford: Oxbow Books, pp. 539-580.

Molavi-Arabshahi M, Arpe K and Leroy SAG (2015) Precipitation and temperature of the Southwest Caspian Sea during the last 55 years, their trends and teleconnections with largescale atmospheric phenomena. International Journal of Climatology. Epub ahead of print 14 September. DOI: 10.1002/ joc. 4483 .

Naderi Beni A, Lahijani H, Mousavi Harami R et al. (2013) Caspian sea-level changes during the last millennium: Historical and geological evidence from the south Caspian Sea. Climate of the Past 9: 1645-1665.

Nokandeh J, Sauer EW, Omrani Rekavandi H et al. (2006) Linear barriers of Northern Iran: The Great Wall of Gorgan and the Wall of Tammishe. Iran 44: 121-173.

Okhravi R and Amini A (2001) Characteristics and provenance of the loess deposits of the Gharatikan watershed in Northeast Iran. Global and Planetary Change 28: 11-22.

Omrani Rekavandi H, Sauer EW, Wilkinson T et al. (2007) An imperial frontier of the Sasanian Empire: Further fieldwork at the Great Wall of Gorgan. Iran 45: 95-136.

Omrani Rekavandi H, Sauer EW, Wilkinson T et al. (2008) Sasanian Walls, Hinterland Fortresses and abandoned ancient irrigated landscapes: The 2007 season on the Great Wall of Gorgan and the Wall of Tammishe. Iran 46: 151-178.

Ponel P, Andrieu-Ponel V, Djamali M et al. (2013) Fossil beetles as possible evidence for transhumance during the middle and late-Holocene in the high mountains of Talysch (Talesh) in NW Iran? Journal of Environmental Archaeology 18(3): 201-210.

Poole I and Gale R (2013) Charcoal. In: Sauer E, Omrani Rekavandi H, Wilkinson TJ et al. (eds) Persia's Imperial Power in Late Antiquity: The Great Wall of Gorgan and Frontier Landscapes of Sasanian Iran. Oxford: Oxbow Books, pp. 581-590.

Priestman S (2013) Sasanian ceramics from the Gorgan Wall and other sites on the Gorgan Plain. In: Sauwer E, Omrani Rekavandi H, Wilkinson TJ et al. (eds) Persia's Imperial Power in Late Antiquity: The Great Wall of Gorgan and Frontier Landscapes of Sasanian Iran. Oxford: Oxbow Books, pp. 447-534.

Rahimi-Laridjani F (1988) Die Entwicklung der Bewässerungslandwirtschaft im Iran bis in sasanidisch-frühislamische Zeit (Beiträge zur Iranistik 13). Wiesbaden: Reichert.

Ramezani E, Joosten H, Marvie Mohadjer MR et al. (2008) The late-Holocene vegetation history of Central Caspian (Hyrcanian) forests of northern Iran. The Holocene 18: 305-319. 
Ramezani E, Mrotzek A, Marvie Mohadjer MR et al. (2016) Between the mountains and the sea: Late-Holocene Caspian Sea level fluctuations and vegetation history of the lowland forests of northern Iran. Quaternary International. DOI: $10.1016 /$ j.quaint.2015.12.041.

Robinson SG (1986) The late Pleistocene palaeoclimatic record of North Atlantic deep-sea sediments revealed by mineralmagnetic measurements. Physics of the Earth and Planetary Interiors 42: 22-47.

Roustaei K (2016) An emerging picture of the Neolithic of Northeast Iran. Iranica Antiqua 51: 21-55.

Roustaei K, Mashkour M and Tengberg M (2015) Tappeh Sang-e Chakhmaq and the beginning of the Neolithic in north-east Iran. Antiquity 89(345): 573-595.

Rychagov GI (1997) Holocene oscilliations of the Caspian Sea and forecasts based on paleogeographical reconstructions. Quaternary International 41/42. 167-172.

Sagheb Talebi K, Sajedi T and Pourhashemi M (2014) Forests of Iran: A Treasure from the Past, a Hope for the Future. Series: Plant and Vegetation, vol. 10. Dordrecht: Springer.

Sauer EW, Omrani Rekavandi H, Wilkinson TJ et al. (2013) Persia's Imperial Power in Late Antiquity: The Great Wall of Gorgan and Frontier Landscapes of Sasanian Iran. Oxford: Oxbow Books.

Schmidt EF (1940) Flights over Ancient Cities of Iran. Chicago, IL: University of Chicago Press.

Scott L (1992) Environmental implications and origin of microscopic Pseudoschizaea Thiergart and Frantz ex R. Potonié emend. in sediments. Journal of Biogeography 19: 349-354.

Sharifi A, Pourmand A, Canuel EA et al. (2015) Abrupt climate variability since the last deglaciation based on a high-resolution, multi-proxy peat record from NW Iran: The hand that rocked the Cradle of Civilization? Quaternary Science Reviews 123: 215-230.

Shiomi H (1976) Archaeological Map of the Gorgān Plain, Iran No. 1. Hiroshima University Scientific Expedition to Iran. Hiroshima: Denshi Insatsu Co. Ltd.

Shiomi H (1978) Archaeological Map of the Gorgān Plain, Iran No. 2. Hiroshima University Scientific Expedition to Iran. Hiroshima: Denshi Insatsu Co. Ltd.

Shumilovskikh LS, Djamali M, Andrieu-Ponel V et al. (submitted) Palaeoecological Insights into Agri-Horti-Cultural and Pastoral Practices before, during and after the Sasanian Empire. In: Sauer EW (ed.) Sasanian Persia: Between Rome and the Steppes of Eurasia. Edinburgh: Edinburgh University Press Ltd.

Soulet G, Ménot G, Garreta V et al. (2011) Black Sea 'Lake' reservoir age evolution since the Last Glacial - Hydrologic and climatic implications. Earth Planetary Science Letters 308: 245-258.
Svensson A, Andersen KK, Bigler M et al. (2008) A 60000 year Greenland stratigraphic ice core chronology. Climate of the Past 4: 47-57.

Talebi T, Ramezani E, Djamali M et al. (2015) The Late-Holocene climate change, vegetation dynamics, lake-level changes and anthropogenic impacts in the Lake Urmia region, NW Iran. Quaternary International. Epub ahead of print 19 December. DOI: 10.1016/j.quaint.2015.11.070.

Terziev SF (1992) Hydrometeorology and Hydrochemistry of Seas, Hydrometeorological Conditions. Leningrad: Gidrometeoizdat.

Thornton CP (2013) The Bronze Age in Northeastern Iran. In: Potts DT (ed.) The Oxford Handbook of Ancient Iran. Oxford: Oxford University Press, pp. 179-202.

Van Geel B (1978) A palaeoecological study of Holocene peat bog sections in Germany and the Netherlands, based on the analysis of pollen, spores and macro- and microscopic remains of fungi, algae, cormophytes and animals. Review of Palaeobotany and Palynology 25: 1-120.

Van Geel B and Aptroot A (2006) Fossil ascomycetes in Quaternary deposits. Nova Hedwigia 82: 313-329.

Van Zeist W (1967) Late Quaternary vegetation history of western Iran. Review of Palaeobotany and Palynology 2: 301-311.

Van Zeist W and Bottema S (1977) Palynological investigations in Western Iran. Palaeohistoria 19: 19-85.

Van Zeist W and Bottema S (1991) Late Quaternary vegetation of the Near East. Beihefte zum Thbinger Atlas des Vorderen Orients, Reihe A 18: 1-156.

Van Zeist W and Wright HE (1963) Preliminary pollen studies at Lake Zeribar, Zagros Mountains, Southwestern Iran. Science 140: $65-67$.

Vorobiova LA (1998) Chemical Analysis of Soils. Moscow: Moscow State University Publishing House (in Russian).

Vorobiova LA (2006) Theory and Practice of the Chemical Analysis of Soils. Moscow: GEOS Publishers (in Russian).

Welter-Schultes F (2012) European Non-Marine Molluscs: A Guide for Species Identification. Göttingen: Planet Poster Edition, 679 pp.

Wilkinson TJ, Omrani Rekavandi H, Hopper K et al. (2013) The landscapes of the Gorgan Wall. In: Sauer EW, Omrani Rekavandi $\mathrm{H}$, Wilkinson $\mathrm{TJ}$ et al. (eds) Persia's Imperial Power in Late Antiquity: The Great Wall of Gorgan and Frontier Landscapes of Sasanian Iran. Oxford: Oxbow Books, pp. 24-132.

Zohary M (1973) Geobotanical Foundations of the Middle East. Stuttgart, Amsterdam: Gustav Fischer Verlag, Zeitlinger.

Zohary M (1981) On the flora and vegetation of the Middle East: Structure and evolution. In: Frey W and Uerpmann H-P (eds) Beiträge zur Umweltgeschichte der Vorderen Orients. Beihefte zum Tübinger Atlas des Vorderen Orients. Reihe A (Naturwissenschaften) Nr. 8. Dr. Wiesbaden: Ludwig Reichert Verlag, pp. 1-25. 